\title{
Physicochemical, Microbial and Ecotoxicological Characteristics of Textile Effluent Collected in the Southeast Region of Brazil
}

\author{
Pedro Henrique Mainardi (Corresponding author) \\ São Paulo State University Júlio de Mesquita Filho (UNESP) \\ Inst. de Biociências/Dept. de Bioquímica e Microbiologia, São Paulo, Brasil \\ Tel: 55-193-526-4192 \\ E-mail: pedro.h.mainardi@unesp.br
}

\section{Ederio Dino Bidoia}

São Paulo State University Júlio de Mesquita Filho (UNESP)

Inst. de Biociências/Dept. de Bioquímica e Microbiologia, São Paulo, Brasil

Tel: 55-193-526-4191_ E-mail: ederio.bidoia@unesp.br

Received: April 3, 2019 Accepted: May 14, 2019 Published: June 17, 2019

doi:10.5296/jee.v10i1.14740 URL: https://doi.org/10.5296/jee.v10i1.14740

\begin{abstract}
The textile sector comprises several segments and detain a great economic and social value. Textile industries, however, demands large amounts of water and generate great loads of effluent in their production process. The effluent's physical and chemical parameters, as much as its microbiological and ecotoxicological aspects, has been extremely useful to find out the key aspects for the development of novel methods of treatment and implementation of new techniques of industrial processing. In this study, a real effluent sample was collected from a textile factory situated in the southeast region of Brazil and analyzed for turbidity, solids content, oils and greases, alkalinity, $\mathrm{pH}$ value, electrical conductivity, BOD, COD, organic and inorganic components, total viable bacteria, coliforms and EC50 ecotoxicological degree using the microcrustacean Daphnia magna and the lettuce Lactuca sativa. The measured parameters were seen to have a great variation in comparison to a vast literature report and the characterization was shown to be extremely important in the search of new methods to reduce the volume and the toxicity of this kind of effluent.
\end{abstract}

Keywords: Wastewater, residue, environmental monitoring, pollution prevention, dyeing industry 


\section{Introduction}

The textile sector is one of the oldest and most traditional in the world, with first report dating back to 3000 BC (Raichurkar and Ramachandran 2015). Today, the textile sector detains a great social and economic importance, comprising several subareas, such as the production and dyeing of yarns and fibers, development and manufacturing of clothing, fashion trends, logistics, retailing and distribution of products (Kozlowski et al. 2016; Agarwal et al. 2017; Todeschini et al. 2017). According to estimates, in the globe, the total market value of the textile industry segment is expected to reach \$842,6 billion in the year of 2020 (Sivaram et al. 2019). In Brazil, in the year of 2017, the textile sector employed about 1.5 million workers with a market value of $\$ 53.4$ billion of dollars (Lucato et al. 2017).

Although its notable economic and social importance, textile industries are known to use large amount of water in their industrial process and generate high quantities of effluent. Around 200 liters of water is used per kilogram of raw material, whereas, approximately 10 to $15 \%$ of that volume is lost in form of effluent (Husain 2006; Ghaly et al. 2014). According to Dey and Islam (2015), small industrial plants generate an average of $8 \mathrm{~m}^{3} / \mathrm{L}$ of effluent per day and may reach around $400 \mathrm{~m}^{3} / \mathrm{L}$ in larger industrial plants. In most of the cases, textile effluents are consisted of a junction of wastes of several industrial processes, which generates a final effluent with a complex characteristic (Beltrame, 2000; Sivaram et al. 2019).

The physicochemical characteristics of textile effluents, such as the turbidity, solids content, $\mathrm{pH}$ value, electrical conductivity, BOD, COD, alkalinity, oils and greases, concentration of organic and inorganic components, has been crucial in the development and implementation of novel methods of treatment (Correia et al. 1994; Bisschops and Spanjers 2003). The microbial and ecotoxicological aspects of the effluent, such as the quantity coliforms and its degree of ecotoxicity, has also been useful in the development of new treatment techniques and environmental management strategies (Sponza 2002; Akpor and Muchie 2011).

The presence of fecal coliforms, a group of bacteria that are present in the intestinal flora of warm-blooded animals, presumes the presence of entero-pathogenies that have the potential to cause infectious diseases in humans, such as those of the genera Escherichia, Klebsiela, Enterobacter, Citrobacter and Serratia (Rompré et al. 2002; Pal 2014). Enteric bacteria, viruses and parasites are known to be responsible for the spread of various waterborne diseases and cause a high mortality rate in the world (Gavrilescu et al. 2015). The examples also include bacteria of the genus Salmonella, Vibrio and Legionella, protozoa such as Giardia lamblia and Cryptosporidium pavrum, as much as viruses such as hepatitis and rotavirus (Akpor and Muchie 2011).

The ecotoxicity, also called environmental toxicology, is the science that evaluates the effect of pollutants from an ecological perspective (Levin et al. 2011). The ecotoxicology assesses the impact of pollutants in the scale of populations, communities and ecosystems, through the use of testing organisms (Hoffman et al. 2002). Ecotoxicological parameters are used to forecast the transformation processes of pollutants in the environment at different trophic levels (Moriarty 1988; Costa et al. 2008; Gavrilescu 2010). In this context, the objective of this study was to collect a sample of textile effluent from a plant located in the southeast 
region of Brazil and characterize it through its physicochemical, microbiological and ecotoxicological aspects.

\section{Material and Methods}

\subsection{Sample Collection}

The raw effluent was collected at 11:00 am in October 2018 from an industrial plant located in the southeast region of Brazil. The industry was currently processing only cotton fibers and generated an average of $40 \mathrm{~m}^{3}$ of effluent per hour. The material was collected before mixing with any traditional sewage or treatment system. The sample was transported and refrigerated maintained until the analysis procedure.

\subsection{UV-VIS Analysis, pH Value and Electrical Conductivity}

The spectrophotometric analyzes were made in the spectrophotometer UV-2401 (Shimadzu) in quartz cuvettes with $4.5 \mathrm{~cm}$ height, $1.2 \mathrm{~cm}$ width and $1.2 \mathrm{~cm}$ depth. The Absorbance scans were performed at the wavelength of 300 to $800 \mathrm{~nm}$, with $1.0 \mathrm{~nm}$ interval between the readings. The readings were made before and after centrifugation at $4000 \mathrm{rpm}$ for 30 minutes. The sample was diluted when necessary. The $\mathrm{pH}$ value of the sample was measured on the $\mathrm{pH}$ meter DMPH-2 (Digimed), calibrated with buffer solution of $\mathrm{pH} 4.0$ and 7.0. The electrical conductivity was measured through the conductivity meter CA150 (Comitec), calibrated in standard conductivity solution.

\subsection{Physicochemical Analysis}

The turbidity measurement was done through the method 2130b, settleable solids through the method 2540f, total suspended solids by the method 2540d, total dissolved solids by the method 2450c, BOD 5 and COD by the methods 5210b and 5220d, alkalinity by method 2320b, oils and greases by method 5520f, total nitrogen by the $4500-\mathrm{N}_{\text {org }} \mathrm{B}$ method, cyanide by $4500-\mathrm{CN}^{-}$de method, chromium by $3500-\mathrm{Crb}$, fluoride by 4500 -fc, sulfide by 4500 -s $2 \mathrm{~d}$ and the total phenol by the 5530cd method (APHA 2017). The concentrations of aluminum, barium, boron, cadmium, calcium, lead, copper, tin, iron, phosphorus, magnesium, manganese, mercury, nickel, potassium, silver, selenium, sodium, zinc were detected by the method 6010c, arsenic by method 7062, ammoniacal nitrogen by the method 350.1, chloride and sulfate by method 300.1 (USEPA 1993; USEPA 1994; USEPA 1997; USEPA 2007). The analyzes of benzene, chloroform, dichloroethenes, styrene, ethylbenzene, trichloroethene, toluene and xylene were done using method 8260d (USEPA 1993).

\subsection{Microbiological Analyzes}

The enumeration of total and fecal coliforms was done through the methods 9222e and 9222e (APHA 2017). The total enumeration of microbial colonies was done by the Drop Plate method, based on Herigstad (2001). The method consisted of adding $50 \mu \mathrm{L}$ of serial dilutions of the sample in peptone water $(0.1 \% \mathrm{w} / \mathrm{v})$ to a quadrant of a petri dish that contained PCA medium. The $50 \mathrm{ul}$ were dispensed separately in 5 drops with a volume of $10 \mu \mathrm{L}$ each. After drying the droplets, the plates were incubated at $35^{\circ} \mathrm{C}$ for 24 hours and analyzed visually for the number of colonies forming units (CFU). The enumeration was done through equation 1. 
Equation 1

$$
U F C m L^{-1}=\frac{N C}{0.05} \times D F
$$

where $N C$ refers to the number of colonies growing in each quadrant of the plate and $D F$ to the sample dilution factor.

\subsection{Ecotoxicological Analyzes}

The $\mathrm{EC}_{20}$ and $\mathrm{EC}_{50}$ indexes were determined by linear regression of the biological factor as a function of the logarithmic effluent concentration (Moriarty 1988). The acute toxicity index was calculated using the mean effective concentration (ATU $\left.=100 / E_{50}\right)$ and classified according to table 1 .

Table 1. Scale of toxicity based on Sanchez et al. (1988).

\begin{tabular}{llll}
\hline Rank & EC50 $(\%)$ & ATU & Class \\
\hline 1 & $<25$ & $>4.0$ & Very Toxic \\
\hline 2 & $26-50$ & $3.9-2.0$ & Moderately toxic \\
\hline 3 & $51-74$ & $1.9-1.4$ & Toxic \\
\hline 4 & $>75$ & $<1.3$ & Slightly \\
\hline 5 & No toxic effect & - & Nontoxic \\
\hline
\end{tabular}

\subsubsection{Immobilization of the Microcrustacean Daphnia Magna}

The acute toxicity test with Daphnia magna microcrustacean was done according to OECD (2004). The experiment was done in quadruplicate test tubes containing $10 \mathrm{~mL}$ of different sample dilutions and 5 microcrustaceans each ( $2 \mathrm{~mL}$ per individual). The exposure time of the test organisms was 48 hours at $20^{\circ} \mathrm{C}$ in the dark. The dilution water and the experiment control had the hardness of $209.52 \mathrm{mg} \mathrm{L}^{-1}\left(\mathrm{CaCO}_{3}\right)$ and $\mathrm{pH}$ value of 7.84 .

\subsubsection{Inhibition of Germination of the Lettuce Lactuca Sativa}

The degree of phytotoxicity was determined by the inhibition of germination of the lettuce Lactuca sativa. The seeds were obtained in commercial packs without the presence of agrochemicals. The experiment was done by adding $3.0 \mathrm{~mL}$ of different sample concentrations and 20 seeds of lettuce in sterile petri dishes containing a filter paper at the bottom. The plates were incubated in a climatic chamber at $21^{\circ} \mathrm{C}$ for $120 \mathrm{~h}$ in the dark. The percentage of inhibition was calculated from Araújo and Monteiro (2005) germination index, using measures of root lengthening and relative germination of the seeds in each plate (Equations 2, 3 and 4). The positive control was done by replacing the sample with zinc sulphate solution $(0.05 \mathrm{M})$ and the negative control with sterile deionized water. The experiment was done in duplicate.

Equation 2 


$$
R L=\left(\frac{R L s}{R L c}\right) \times 100
$$

Equation 3

$$
R G=\left(\frac{G S s}{G S c}\right) \times 100
$$

Equation 4

$$
G I N=100-\left[\frac{(R L \times R G)}{100}\right]
$$

where $R L$ refers to the relative root length (\%), $R L s$ to the mean root length of the seeds on the plate with the sample, $R L c$ to the mean root length of the seeds in the control plate, $R G$ to the relative germination index (\%), GSs to the number of seeds that germinated on the plate containing the sample, GSc to the number of seeds that germinated in the control plate, GIN to the germination inhibition index (\%).

\section{Results}

\subsection{Effluent Characteristics}

The textile effluent had an unpleasant odor, with a turbidity index of 650 NTU and highest absorbance of 0.28 (dilution 1:64) at the wavelength region of $667 \mathrm{~nm}\left(\lambda_{\max }\right)$ (Figure 1). There was the quantity of $1.0 \mathrm{~mL} \mathrm{~L}^{-1}$ of settleable and $6790 \mathrm{mg} \mathrm{L}^{-1}$ of total solids. The effluent had an alkalinity value of $4200 \mathrm{mg} \mathrm{CaCO}_{3} \mathrm{~L}^{-1}$, the amount of $33.8 \mathrm{mg} \mathrm{L}^{-1}$ of oils and greases, $\mathrm{pH}$ value of 10.31 units and electrical conductivity of $7260 \mu \mathrm{S} / \mathrm{cm}$. The $\mathrm{BOD}_{5}$ and COD values were 1747 and $3595 \mathrm{mg} \mathrm{L}^{-1}$, with a BOD/COD factor of 0.49 . The microbial enumeration indicated the presence of $5,3 \times 10^{5} \mathrm{UFC} \mathrm{mL}^{-1}$ of cultivable bacteria, 2,0 $\mathrm{x} 10^{2}$ UFC $\mathrm{mL}^{-1}$ of total coliforms and 1,0 $\times 10^{2} \mathrm{UFC} \mathrm{mL}^{-1}$ fecal coliforms. The ecotoxicological test with $D$. magna and $L$. sativa indicated $\mathrm{EC}_{50}$ values of $3.04 \%$ and $66.24 \%$. The concentrations of heavy metals, trace elements, organic and inorganic components are cited in table 2 . 


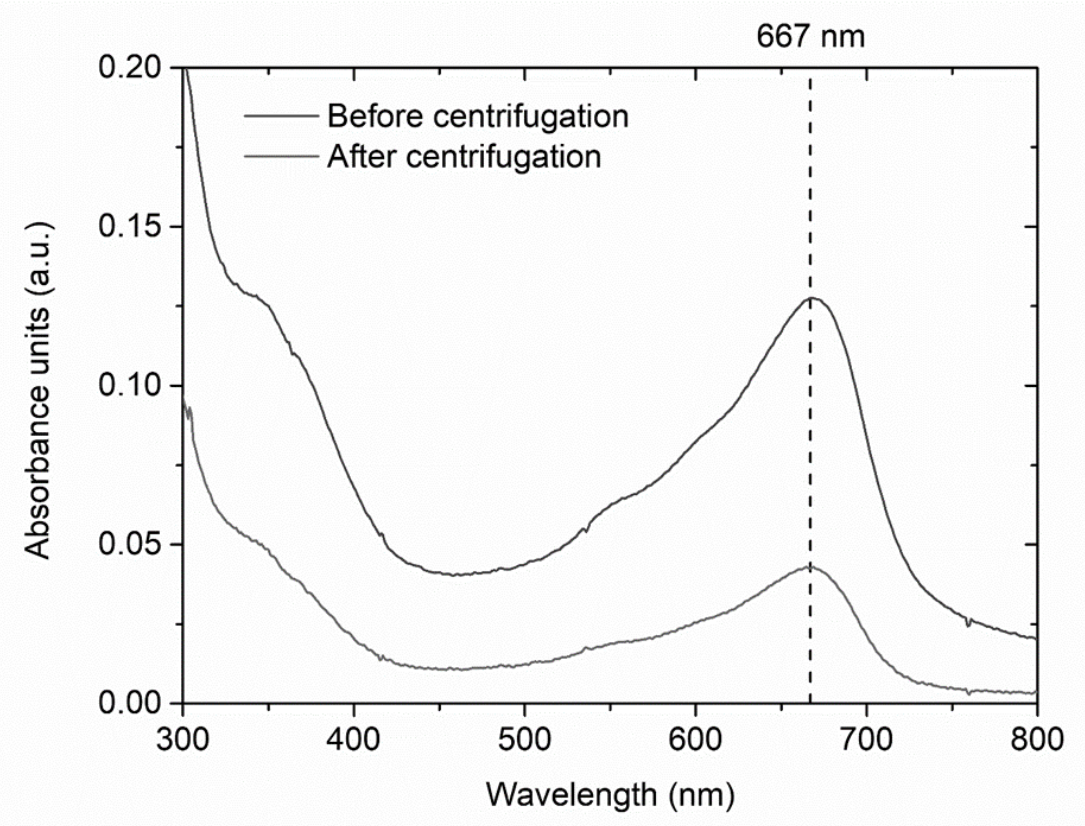

Figure 1. Absorbance units in function of textile effluent wavelength at 1:64 dilution rate.

Table 2. Parameters of the textile effluent.

\begin{tabular}{lll}
\hline Parameter & Result & Unit \\
\hline Odor & Unpleasant/Pungent & - \\
\hline Turbidity & 650 & $\mathrm{NTU}$ \\
\hline$\lambda_{\max }$ & 667 & $\mathrm{~nm}$ \\
\hline Settleable solids & 1.0 & $\mathrm{~mL} \mathrm{~L}^{-1}$ \\
\hline Total suspended solids & 395 & $\mathrm{mg} \mathrm{L}^{-1}$ \\
\hline Total dissolved solids & 6395 & $\mathrm{mg} \mathrm{L}^{-1}$ \\
\hline Total solids & 6790 & $\mathrm{mg} \mathrm{L}^{-1}$ \\
\hline pH & 10.31 & \\
\hline Electric conductivity & 7260 & $\mu \mathrm{cm}$ \\
\hline BOD5 & 1747 & $\mathrm{mg} \mathrm{L}^{-1}$ \\
\hline COD & 3595 & $\mathrm{mg} \mathrm{L}^{-1}$ \\
\hline BOD/COD & 0.49 & - \\
\hline Alkalinity & 4200 & $\mathrm{mgCaCO}^{-1}$ \\
\hline Oils and grease & 33.8 & $\mathrm{mg} \mathrm{L}^{-1}$ \\
\hline Aluminum & 0.104 & $\mathrm{mg} \mathrm{L}^{-1}$ \\
\hline Arsenic & $<0.005$ & $\mathrm{mg} \mathrm{L}^{-1}$ \\
\hline Barium & 0.025 & $\mathrm{mg} \mathrm{L}^{-1}$ \\
\hline Boron & 0.125 & $\mathrm{mg} \mathrm{L}^{-1}$ \\
\hline Cadmium & $<0.001$ & $\mathrm{mg} \mathrm{L}^{-1}$ \\
\hline & & \\
\hline
\end{tabular}




\begin{tabular}{|c|c|c|}
\hline Parameter & Result & Unit \\
\hline Calcium & $<1000$ & $\mathrm{mg} \mathrm{L}^{-1}$ \\
\hline Lead & $<0.005$ & $\mathrm{mg} \mathrm{L}^{-1}$ \\
\hline Chloride & 95.80 & $\mathrm{mg} \mathrm{L}^{-1}$ \\
\hline Copper & 0.015 & $\mathrm{mg} \mathrm{L}^{-1}$ \\
\hline Chromium & 0.036 & $\mathrm{mg} \mathrm{L}^{-1}$ \\
\hline Tin & 0.013 & $\mathrm{mg} \mathrm{L}^{-1}$ \\
\hline Iron & 0.303 & $\mathrm{mg} \mathrm{L}^{-1}$ \\
\hline Fluoride & 0.253 & $\mathrm{mg} \mathrm{F}^{-} \mathrm{L}^{-1}$ \\
\hline Phosphor & 21.30 & $\mathrm{mg} \mathrm{L}^{-1}$ \\
\hline Magnesium & 15.00 & $\mathrm{mg} \mathrm{L}^{-1}$ \\
\hline Manganese & 0.045 & $\mathrm{mg} \mathrm{L}^{-1}$ \\
\hline Mercury & $<0.0002$ & $\mathrm{mg} \mathrm{L}^{-1}$ \\
\hline Nickel & 0.063 & $\mathrm{mg} \mathrm{L}^{-1}$ \\
\hline Nitrogen & 230 & $m g \mathrm{~N} \mathrm{~L}^{-1}$ \\
\hline Ammoniacal Nitrogen & 3.42 & $\mathrm{mg} \mathrm{NH}_{3} \mathrm{~L}^{-1}$ \\
\hline Potassium & 355 & $\mathrm{mg} \mathrm{L}^{-1}$ \\
\hline Silver & $<0.005$ & $\mathrm{mg} \mathrm{L}^{-1}$ \\
\hline Selenium & $<0.005$ & $\mathrm{mg} \mathrm{L}^{-1}$ \\
\hline Silica & $<2500$ & $\mathrm{mg} \mathrm{SiO} \mathrm{L}^{-1}$ \\
\hline Sodium & 227 & $\mathrm{mg} \mathrm{L}^{-1}$ \\
\hline Sulphate & 1985 & $\mathrm{mg} \mathrm{L}^{-1}$ \\
\hline Sulfide & 1.907 & $\mathrm{mg} \mathrm{S}^{2-} \mathrm{L}^{-1}$ \\
\hline Zinc & 0.167 & $\mathrm{mg} \mathrm{L}^{-1}$ \\
\hline Benzene & $<0.001$ & $\mathrm{mg} \mathrm{L}^{-1}$ \\
\hline Chloroform & $<0.001$ & $\mathrm{mg} \mathrm{L}^{-1}$ \\
\hline Cyanide & $<0.010$ & $\mathrm{mg} \mathrm{CN}^{-} \mathrm{L}^{-1}$ \\
\hline 1,2-dichloroethene & $<0.001$ & $\mathrm{mg} \mathrm{L}^{-1}$ \\
\hline Styrene & $<0.001$ & $\mathrm{mg} \mathrm{L}^{-1}$ \\
\hline Ethylbenzene & $<0.001$ & $\mathrm{mg} \mathrm{L}^{-1}$ \\
\hline Total Phenols & $<0.001$ & $\mathrm{mg} \mathrm{L}^{-1}$ \\
\hline Carbon tetrachloride & $<0.001$ & $\mathrm{mg} \mathrm{L}^{-1}$ \\
\hline Toluene & $<0.001$ & $\mathrm{mg} \mathrm{L}^{-1}$ \\
\hline Trichlorethylene & $<0.001$ & $\mathrm{mg} \mathrm{L}^{-1}$ \\
\hline Xylene & $<0.001$ & $\mathrm{mg} \mathrm{L}^{-1}$ \\
\hline Total viable microbial count & $5.3 \times 10^{5}$ & UFC $\mathrm{mL}^{-1}$ \\
\hline
\end{tabular}




\begin{tabular}{lll}
\hline Parameter & Result & Unit \\
\hline Total coliforms & $2.0 \times 10^{2}$ & UFC mL $\mathrm{mL}^{-1}$ \\
\hline Total fecal coliforms & $1.0 \times 10^{2}$ & UFC mL \\
\hline D. magna $\left(\right.$ EC $\left._{50}\right)$ & 3.04 & $\%$ \\
\hline L. sativa $\left(\right.$ EC50) $^{-1}$ & 66.24 & $\%$ \\
\hline
\end{tabular}

\section{Discussion}

\subsection{Odor}

The effluent had an unpleasant odor, probably due the presence of volatile components, so called volatile organic compounds (VOC) or air toxics. Those components, which include nitrous gases, sulfur compounds and aromatic hydrocarbons, are known to be harmful to humans, the environment, and also may modify the composition of the atmospheric air (Müezzinoğlu 1998; Pereira 2002; Dey and Islam 2015). The implementation of air filters had been proved as a feasible method for lowering the emission of air pollutants by industrial plants (Leson and Winer 1991; Subrenat and Le Cloirec 2006). The replace of traditional chemicals to less-toxic ones, the optimization of the industrial operations and better agroforestry management were also recommended to reduce the emission of air pollutants (Müezzinoğlu 1998).

\section{$4.2 \mathrm{pH}$ Value}

The $\mathrm{pH}$ directly affects the capacity of water buffering, interfere the chemical reactions, the metabolism of living organisms and were proven to cause great influence in aquatics and terrestrial ecosystems (Goodwin et al. 1988; Beltrame 2000; ŠImek and Cooper 2002; Lacoul and Freedman 2006; Hartman 2008; Wootton and Forester 2008; Favas et al. 2016; Gómez et al. 2017). The vast majority of fishes, for example, only survive in a narrow $\mathrm{pH}$ range of 6-9 (Dey and Islam 2015). The alkaline $\mathrm{pH}$ of 10.31 is due the use of hydroxide and sodium carbonate, commonly used in the processing of cotton fibers (Rodrigues et al. 2013). Literature reports, indeed, indicated a high variation in this parameter, with $\mathrm{pH}$ values ranging from acid 3.0 to alkaline 13.0 (Table 3).

The high $\mathrm{pH}$ variation is due to the use of a great diversity of chemical reagents and different types of raw materials in the textile processing (Correia et al. 1994; Verma et al. 2012; dos Santos 2018). In addition, effluents of this type, in most cases, are composed of mixtures from several different industrial processes (Beltrame 2000; Sivaram 2019). In general, the $\mathrm{pH}$ of the effluent is neutralized in the early stages of the treatment process, called equalization or neutralization steps (Kunz et al. 2002; Powar et al., 2012). The pH adjustment had been crucial in most treatment techniques, especially the biological ones, such as activated sludge and anaerobic reactors (Lin and Peng 1994; Rajeshwari et al. 2000; Rai et al. 2005; Sarayu and Sandhya 2012).

\subsection{Electrical Conductivity}

The electrical conductivity is the capability of a material being able to conduct an electric 
current (Lee et al. 2012). The electrical conductivity is used to quantity the ionic content of aqueous solutions and the dissolved salts that are present in a solvent, an important parameter for water reuse (Chuang et al. 2007; Torres et al. 2009). The high value of $7260 \mu \mathrm{S} / \mathrm{cm}$ seen the effluent is due to the use of high concentrations of salts used to fix the dyes to the fibers, such as chloride and sodium sulfate (Khatri et al. 2015). Reports in the literature indicated values between 653 and $29800 \mu \mathrm{S} / \mathrm{cm}$ (Table 3). The high concentration of dissolved salts in this type of effluent is worrying, since they are not possible to be removed by conventional treatment methods (Sultana et al. 2013). In general, effluents with an electrical conductivity above $2,000 \mu \mathrm{S} / \mathrm{cm}$ tend to cause adverse effects on freshwater species and the life of aquatic organisms (Goodfellow, 2000; Morrison 2001). Membrane filtration methods, such as electrodialysis, nanofiltration and reverse osmosis, had been efficiently used in the salt removal of industrial effluents (Bes-Piá 2005; Greenlee 2009; Van der Bruggen et al. 2017).

\subsection{BOD and COD}

The BOD and COD, which refers to the aerobic microbial and chemical decomposition of the organic matter, as much the BOD/COD ratio, are parameters that allow the classification of the biodegradability of effluents (Samudro and Mangkoedihardjo 2010). According to the results, the values of $1747 \mathrm{mg} \mathrm{L}^{-1}$ of BOD and $3595 \mathrm{mg} \mathrm{L}^{-1}$ of COD indicated a mean presence of non-biodegradable organic matter, with a BOD/COD ratio of 0.49 . Literature reports, however, indicated studies with extremely low BOD/COD ratio, with values around 0.01 units (Table 3).

Values below 0.25 in the BOD/COD rate presume the presence of large proportions of non-biodegradable organic matter, such as humic and fulvic acids, as well as large amounts of suspended solids such as salts, chlorides, carbonates, ammonia and sodium (Al-Kdasi et al. 2004; Samudro and Mangkoedihardjo 2010). Molecules with high molecular weight and complex chemical structure, such as dyes and fibers residues, also have a significant influence in the non-biodegradable organic matter content of textile effluents (Akpor and Muchie 2011; Dey and Islam 2015). Chemical and oxidative treatments such as coagulation/flocculation, electro-fenton and ozonation had been efficiently used to reduce the non-biodegradable organic matter in textile effluents (Ramesh et al. 2017; Roshini et al. 2017; Favero et al. 2018; Ulucan-Altuntas and Ilhan 2018). The use of anaerobic bioreactors had also been shown to achieve considerable performance in the reduction of non-biodegradable organic matter content in this type of effluent (Bhattacharjee 2017).

\subsection{Turbidity and Coloration}

The 650 NTU of turbidity indicated the presence of high quantity of colloidal substances and suspended matter (Hongve and Åkesson 1996). The turbidity index also includes yarns, lint, rags and a proportion of dyes that did not bind the fibers during the industrial process (Guaratini and Zanoni 2000; Carmen and Daniela 2012; Ghaly et al. 2014; Chandran 2016). The parameter was seen to have a great variation, since the textile production processes are closed related to fashion trends (O’Neill 1999) (Table 3). High colored effluents represent a major environmental risk since they alter directly the visual appearance of water. They are responsible for influencing the rate of photosynthesis and the eutrophication of water bodies 
(Pierce 1994; Beltrame 2000; Sarayu and Sandhya 2012; Favas et al. 2016; Gómez et al. 2017).

Chemical and biological methods were proven to have good efficiency in the removal of color in textile effluents. Those methods include ozonation, coagulation and biological treatment with specialized microbial strains (Kapdan and Alparslan 2005; Jadhav et al. 2010; Verma et al. 2012; Rodrigues 2013; Cardoso et al. 2016; Holkar 2016; Xu et al. 2018). The integration of different types of treatment methods, indeed, were seen to improve the efficiency of color removal in textile effluents (Manenti et al. 2014; Nawaz and Ahsan 2014; Dasgupta et al. 2015). Mostly, the implementation of environmentally friendly industrial processes, such as the use of natural dyes, development of novel pre-treatment techniques of the raw material and more sophisticated dyeing methods were suggested to reduce the amount of dyes released by this type of effluent (Khatri et al. 2015; Siddiqua et al. 2017; Periyasamy et al. 2017; Kumar and Gunasundari 2018).

\subsection{Solids Content}

The $6790 \mathrm{mg} \mathrm{L}^{-1}$ of total solids indicated the presence of colloidal particles, such as yarns and lint, that are released from the fibers. The parameter also includes acids, alkalis and salts that are used in the textile processing. (Correia et al. 1994; Ghaly et al. 2014; Chandran 2016). The solids content, as shown in figure 1, significantly influenced the spectrophotometric analyzes. In excess, those solids may interfere in the oxygenation of water bodies, reduce the photosynthesis rate and cause adverse effects on the water quality of aquatic ecosystems (Dey and Islam 2015; Favas et al. 2016). In industrial scales, the removal of solids is generally done on the first steps of treatment, with methods like filtration, gravity separation, sedimentation, flotation and coagulation (Carmen and Daniela 2012; Ghaly et al. 2014). Due to the high solids content, the treatment of this type of effluent generally produces large amounts of residual sludge. The quantity, however, differs considerably between the different types of industrial processes and raw materials (Table 3).

\subsection{Oils and Grease}

The amount of $34 \mathrm{mg} \mathrm{L}^{-1}$ of oil and grease found in the effluent sample, which in this case, referred to the hydrocarbons and fatty acids able to be solubilized in hexane, was above the recommended limit of $10 \mathrm{mg} \mathrm{L}^{-1}$ (Abo-Elela et al. 1998). As expected, it was also observed a high variation in this parameter, from values ranging from 6 to $2370 \mathrm{mg} \mathrm{L}^{-1}$ (Table 3). The presence of oils and greases in this type of effluent is due to the use of fatty acid and non-polar hydrocarbon reagents in the industrial processing, like surfactants, waxes, soaps, softeners, oils and lubricants, as well as refectory discards in some cases (Correia et al. 1994; Beltrame 2000; Bisschops and Spanjers 2003; Dey and Islam 2015).

If released into bodies of water, oils and greases can form a film on the surface of the fluid, changing its oxygen transfer rate and severe damage to the aquatic life (Ghaly 2014; Kolhe and Pawar 2011). The removal of oils and grease from effluents is usually done in the first stages of the treatment, in so-called separation tanks (Abo-Elela 1988; Ghaly 2014). Adsorption and electrochemical methods were seen to reduce efficiently the concentration of 
this parameter in industrial effluents (Chen 2004; Rincón and La Motta 2014; Hamid et al. 2016). The biological treatment had also demonstrated good efficiency in the removal of oils and greases from industrial effluents, especially the anaerobic digestion, due to the possibility to produce biogas as part of the treatment process (El-Bestawy et al. 2005; Salama et al. 2019).

\subsection{Alkalinity}

Alkalinity refers to the water capacity of neutralizing a weak acid (Wurts and Durborow 1992; Sudhanya and Chinnamma 2018). The high amount of $4200 \mathrm{mg} \mathrm{L}^{-1}$ of $\mathrm{CaCO}_{3}$ detected in our analyzes is mainly due to the use of large amounts of sodium hydroxide, sodium carbonate and sodium bicarbonate in several stages of textile processing (Beltrame 2000; Rodrigues et al. 2013; Khatri et al. 2015; Tchamango et al. 2017). High alkalinity effluent values, which were seen to have a great variation among others authors (Table 3), were seen to cause significantly changes in the physiological mechanism of plants roots and increase the ecotoxicity degree of samples due the formation of the ammonia through influences in the solution pH (Clément and Merlin 1995; de la Torre-González et al. 2018).

\subsection{Microbiological Parameters}

According to the microbial analyses, the effluent had the quantity of $5.3 \times 10^{5} \mathrm{CFU} \mathrm{mL} \mathrm{m}^{-1}$ of viable bacteria. The value of this parameter, as the physicochemical ones, varied considerably among others researches from the literature, with enumerations that ranged from $3.9 \times 10$ to $6.11 \times 10^{7} \mathrm{CFU} \mathrm{mL} \mathrm{m}^{-1}$. The amount of $2.0 \times 10^{2} \mathrm{CFU} \mathrm{mL}^{-1}$ of total coliforms and $1.0 \times 10^{2}$ CFU $\mathrm{mL}^{-1}$ of fecal coliforms, although not well reported, had also great variance in comparison to others researchers in the literature (Table 3). In textile effluents, microbial diversity studies indicated the presence of bacteria of the genus Pseudomonas, Enterobacter, Alcaligenes, Bacillus, Serattia, Erysipelothrix, Amphibacillus, Micrococcus, Listeria, Nocardia and fungi from the genus Aspergillus, Penicillium, Candida and Rhizopus (Faryal and Hameed 2005; Mahbub et al. 2012; Hassan et al. 2013; Damodaran et al. 2017; Saha et al. 2017; Jayaseelan et al. 2018; Roy et al. 2018). Oxidative methods such as UV disinfection, chlorination, ozonation, photo-fenton, ultrasonic methods, membrane filtration, and the use of nanoparticles, had been used in the elimination and inactivation of pathogens in the treatment of wastewaters (Yasar et al. 2007; Giwa and Ogunribido 2012; Kumar et al. 2017; Gomes et al. 2019; Amabilis-Sosa et al. 2018; De la Obra Jímenez et al. 2019). The resistance of the pathogens, however, can vary considerably among the treatment processes (Hirn 1980). 
Table 3. Physiochemical and microbial parameters of different studies with textile effluent.

\begin{tabular}{|c|c|c|c|c|c|c|c|c|c|c|c|c|c|c|c|c|}
\hline 垔 & 됭 & Оิ & Оิ & 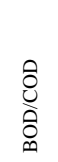 & 窨 & $\begin{array}{l}\text { 范 } \\
\text { 䁬 }\end{array}$ & 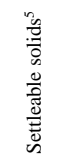 & 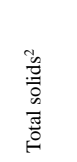 & 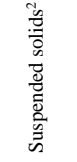 & 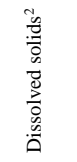 & 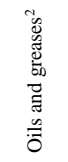 & 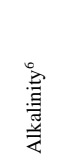 & 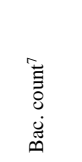 & 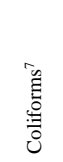 & 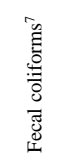 & 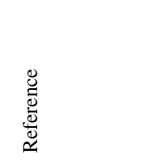 \\
\hline \multirow[t]{2}{*}{10.31} & 7260 & 1747 & 3595 & 0.49 & 650 & 667 & 1.0 & 6790 & 395 & 6395 & 34 & 4200 & $5.3 \mathrm{x}$ & $2.0 \mathrm{x}$ & $1.0 \mathrm{x}$ & Actual study \\
\hline & & & & & & & & & & & & & $10^{5}$ & $10^{2}$ & $10^{2}$ & \\
\hline \multirow{2}{*}{$\begin{array}{c}11.59 \\
-\end{array}$} & - & - & $331-$ & - & - & 450 & $0.1-$ & $2008-$ & $26-$ & $1988-$ & 74 & 5209 & - & - & - & Beltrame 2000 \\
\hline & & & 1473 & & & 600 & 0.4 & 8802 & 75 & 8739 & & & & & & \\
\hline \multicolumn{17}{|l|}{12.87} \\
\hline \multirow{2}{*}{10.21} & - & $163-$ & 1067 & - & - & - & - & - & $35-$ & $250-$ & $6-8$ & - & - & - & - & Yusuff and \\
\hline & & 645 & - & & & & & & 1200 & 2200 & & & & & & Sonibare 2004 \\
\hline \multicolumn{2}{|l|}{11.53} & & 2430 & & & & & & & & & & & & & \\
\hline \multirow[t]{2}{*}{12.00} & - & - & - & - & 49 & - & - & - & - & - & - & - & - & - & - & Bes-Piá et al. \\
\hline & & & & & & & & & & & & & & & & 2005 \\
\hline \multirow[t]{2}{*}{9.90} & - & 1626 & 2190 & 0.74 & - & - & - & 7333 & 210 & - & - & 946 & - & - & - & Kaushik et al. \\
\hline & & & & & & & & & & & & & & & & 2005 \\
\hline 10.00 & - & 170 & 1150 & 0.15 & - & - & - & - & 150 & - & - & - & - & - & - & Selcuk 2005 \\
\hline \multirow{4}{*}{$\begin{array}{l}8.06- \\
12.44\end{array}$} & $1070-$ & $70-$ & $448-$ & - & - & - & - & $1636-$ & 416 - & $1230-$ & - & - & 0.001 & - & - & Faryal and \\
\hline & 5810 & 553 & 2080 & & & & & 20318 & 15343 & 4975 & & & $\mathrm{x} 10^{3}-$ & & & Hameed 2005 \\
\hline & & & & & & & & & & & & & $5.0 \mathrm{x}$ & & & \\
\hline & & & & & & & & & & & & & $10^{3}$ & & & \\
\hline \multirow{2}{*}{$\begin{array}{l}7.20- \\
7.60\end{array}$} & 653 & - & - & - & $25-$ & - & - & - & - & - & - & - & - & - & - & Choo et al. 2007 \\
\hline & & & & & 31 & & & & & & & & & & & \\
\hline \multirow{4}{*}{$\begin{array}{l}7.70- \\
11.90\end{array}$} & - & $243-$ & 1088 & - & - & - & - & $1647-$ & $416-$ & $1231-$ & - & - & $0.21 \mathrm{x}$ & - & - & Ali et al. 2009 \\
\hline & & 848 & - & & & & & 19297 & 15449 & 3850 & & & $10^{5}-$ & & & \\
\hline & & & 2080 & & & & & & & & & & $11.5 \mathrm{x}$ & & & \\
\hline & & & & & & & & & & & & & $10^{5}$ & & & \\
\hline \multirow{2}{*}{$\begin{array}{l}7.12- \\
12.99\end{array}$} & - & - & 350 & - & - & - & - & $2000-$ & $300-$ & - & $160-$ & - & - & - & - & Ogunlaja and \\
\hline & & & & & & & & $31800-$ & 780 & & 2370 & & & & & Aemere 2009 \\
\hline \multirow[t]{2}{*}{-} & - & - & - & - & - & - & - & - & - & - & - & - & $5.8 \mathrm{x}$ & $2.4 \mathrm{x}$ & $2.4 \mathrm{x}$ & Das et al. 2010 \\
\hline & & & & & & & & & & & & & $10^{6}$ & 10 & 10 & \\
\hline \multirow[t]{2}{*}{7.51} & 9565 & 275 & 789 & 0.35 & - & - & - & 7625 & 1750 & 5875 & - & - & $11.6 \mathrm{x}$ & - & - & Prasad and Rao \\
\hline & & & & & & & & & & & & & $10^{5}$ & & & 2011 \\
\hline \multirow{2}{*}{$\begin{array}{l}7.71- \\
8.20\end{array}$} & - & 130 - & 381 - & - & - & - & - & - & - & 3896 - & - & $280-$ & - & - & - & Paul et al. 2012 \\
\hline & & 500 & 1548 & & & & & & & 7072 & & 500 & & & & \\
\hline \multirow[t]{2}{*}{-} & - & - & - & - & - & - & - & - & - & - & - & - & $2.8 \mathrm{x}$ & - & - & Hassan et al. 2013 \\
\hline & & & & & & & & & & & & & $10^{7}$ & & & \\
\hline \multirow[t]{2}{*}{11.30} & 18000 & 200 & 1200 & 0.16 & - & 641 & - & - & - & - & - & - & - & - & - & Manenti et al. \\
\hline & & & & & & & & & & & & & & & & 2014 \\
\hline \multirow{3}{*}{$\begin{array}{l}9.17 \text { - } \\
11.80\end{array}$} & - & $800-$ & 1766 & - & - & 487 & - & 1977 - & $447-$ & $1530-$ & - & - & $>1.0 \mathrm{x}$ & $>1.0$ & - & Iqbal and Nisar \\
\hline & & 895 & - & & & 539 & & 2170 & 505 & 1665 & & & $10^{6}$ & $\times 10^{5}$ & & 2015 \\
\hline & & & 2100 & & & 625 & & & & & & & & & & \\
\hline 8.25 & - & 380 & 624 & 0.61 & - & 468 & - & 1300 & 380 & 920 & - & - & - & - & - & Jadhav et al. 2015 \\
\hline \multirow[t]{2}{*}{8.30} & - & 411 & 1309 & 0.31 & - & - & - & 559 & 96 & 463 & - & - & $3.9 x$ & $2.1 \mathrm{x}$ & - & Islam et al. 2015 \\
\hline & & & & & & & & & & & & & 10 & $10^{3}$ & & \\
\hline
\end{tabular}




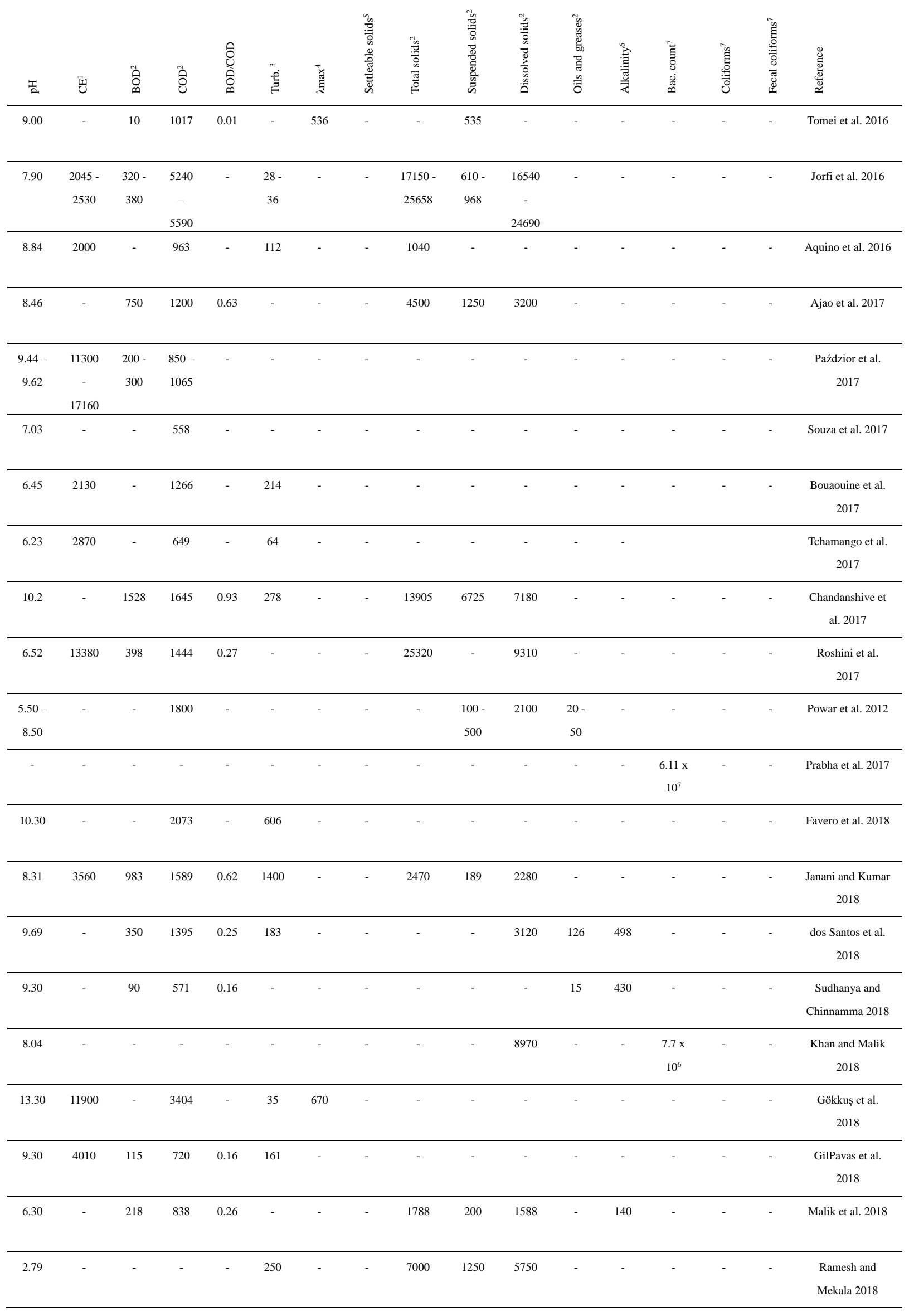




\begin{tabular}{|c|c|c|c|c|c|c|c|c|c|c|c|c|c|c|c|c|}
\hline 吾 & 됩 & 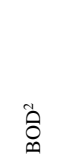 & ठี & 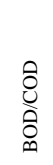 & $\stackrel{m}{\text { 音 }}$ & 筪 & 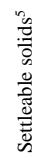 & 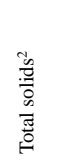 & 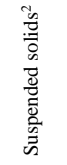 & 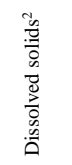 & 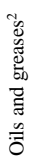 & 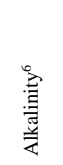 & 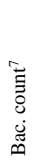 & 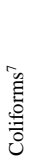 & 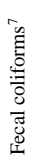 & 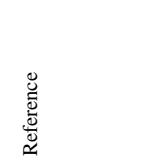 \\
\hline 5.23 & 2811 & 1400 & 2022 & 0.70 & 735 & - & - & - & - & 1367 & - & 1000 & - & - & - & $\begin{array}{c}\text { Sánchez-Sánchez } \\
\text { et al. } 2018\end{array}$ \\
\hline 7.80 & 8400 & 190 & 493 & 0.39 & - & - & $38^{2}$ & 5420 & 324 & 5164 & - & - & - & - & - & $\begin{array}{l}\text { Hussain et al. } \\
2018\end{array}$ \\
\hline $\begin{array}{l}8.05- \\
10.59\end{array}$ & $\begin{array}{l}7168- \\
29800\end{array}$ & $\begin{array}{l}400- \\
564\end{array}$ & $\begin{array}{l}486- \\
2436\end{array}$ & - & - & - & - & $\begin{array}{l}5012- \\
8596\end{array}$ & $\begin{array}{l}222- \\
1890\end{array}$ & $\begin{array}{c}4790- \\
6706\end{array}$ & - & $\begin{array}{l}235- \\
2158\end{array}$ & - & - & - & Singare 2019 \\
\hline 9.84 & - & 200 & 544 & 0.70 & - & - & - & - & 59400 & 50800 & - & - & - & - & - & Kaur et al. 2019 \\
\hline
\end{tabular}

1: $\mu$ s cm-1; 2: mg L-1; 3: NTU; 4: nm; 5: mL L-1; 6: mg CaCO3 L-1; 7: UFC mL-1.

\subsection{Inorganic Components}

\subsubsection{Sodium and Chloride}

The concentrations of $227 \mathrm{mg} \mathrm{L}^{-1}$ of sodium and $96 \mathrm{mg} \mathrm{L}^{-1}$ of chloride were lower than most of the reports seen in the literature, with maximum reported concentrations of $1560 \mathrm{mg} \mathrm{L}^{-1}$ sodium and $34000 \mathrm{mg} \mathrm{L}^{-1}$ of chloride (Table 4). Although the presence of sodium chloride is undoubtedly necessary for the health of the animals, in excess, salt can lead to poisoning, cause acute, chronic toxicologic effects and promote severe changes in the biodiversity of aquatic and terrestrial communities (Weber-Scannell and Duffy 2007; Sultana et al. 2013; Thompson 2018). Salts in excess are also responsible for reducing the osmotic potential of the soil, prevents the water absorption of seeds and inhibits the growth of plants (Flowers et al. 2014; Geilfus et al. 2018; Roy et al. 2018). According to Gardiner and Borne (1978), concentrations above $50 \mathrm{mg} \mathrm{L}^{-1}$ of chloride are already sufficient to adversely affect the growth of plants.

The high salinity detected in textile effluents is due to the use of large amounts of salts and alkalinizes for dyeing fixing, such as sodium chloride, sodium carbonate, sodium bicarbonate and sodium hydroxide (Correia et al. 1994; Rodrigues et al. 2013). Depending on the type of fiber, chemical structure of the dye and dyeing method, the amount of salt used can reach two kilogram per kilogram of processed raw material (Khatri et al. 2015). As discussed above, the concentration of dissolved salts in this effluent represent a major environmental problem since they are not possible to be removed by conventional treatment methods.

Membrane filtration techniques, such as reverse osmosis and electrodialysis methods, had been successfully used in the removal of the dissolved salts from industrial effluents (Ciardelli et al. 2001; Fersi et al. 2005; Lafi et al. 2018). The development of novel, sustainable and environmentally friendly dyeing methods had also been frequently considered by the researchers. The strategies include the development of new type of dyes, modifications in the actual machinery and industrial processes, pre-modification of the textile fibers and use of natural compounds in the textile processing (Khatri et al. 2015; Periyasamy et al. 2017; Hussain and Wahab 2018; Kumar and Gunasundari 2018). 


\subsubsection{Sulphate}

The amount of $1985 \mathrm{mg} \mathrm{L}^{-1}$ of sulphate was above the values seen in the literature, with maximum concentration reported of $1118 \mathrm{mg} \mathrm{L}^{-1}$ (Table 4). Sulphate is a stable and soluble compound, commonly founded in surface and ground waters (Kolhe and Pawar 2011). Sulphate comes from the dyeing baths made with sulfur-based dyes and from the use of auxiliary reagents in several stages of the processing, such as sodium sulphate, sodium hydrosulphite and sulfuric acid (Correia et al. 1994; Beltrame 2000; Bisschops and Spanjers 2003). In fact, the presence of sulphates is worrying because under high concentrations of organic matter and low oxygenation, the compound can be converted to sulphite and form the hydrogen sulphide, a toxic and unpleasant gas (Dey and Islam 2015). Sulphite can also be oxidized to sulfuric acid, a corrosive and toxic compound (Beltrame 2000). Effluents with sulphate concentrations above $300 \mathrm{mg} \mathrm{L}^{-1}$ are considered to be of concern when discarded in traditional sewage networks (Gardiner and Borne 1978).

\subsubsection{Nitrogen, Phosphorus and Potassium}

The amount of $230 \mathrm{mg} \mathrm{L}^{-1}$ of nitrogen, a crucial element for the development of living organisms, was within the values seen in the literature, with a maximum reported concentration of $246 \mathrm{mg} \mathrm{L}^{-1}$ (Table 4). Nitrogen is an important parameter in wastewater, since at concentrations above $10 \mathrm{mg} \mathrm{L}^{-1}$, it may already have negative impacts on the environment and human health (Akpor and Muchie 2011). Nitrogen in textile effluents comes mainly from the dyes used in processing, especially those containing the azo group (Bisschops and Spanjers 2003). Other reagents used in the dyebaths, in the printing and coating stages, such as urea, ammonia acetate and ammonium sulfate, also contributes to the concentration of nitrogen seen in this type of effluent (Sarayu and Sandhya 2012).

The amounts of $355 \mathrm{mg} \mathrm{L}^{-1}$ of potassium and $21 \mathrm{mg} \mathrm{L}^{-1}$ of phosphorus detected in the effluent were close to values reported by other researchers, as demonstrated in table 4 . These components are derived from the use of auxiliary reagents during the dyeing, mercerization and bleaching steps, such as potassium dichromate, ammonium phosphate, phosphorus alcohols and sodium phosphate (Beltrame 2000; Sarayu and Sandhya 2012; Dey and Islam 2015). Effluents with high nutrient content, if discarded directly into water bodies, can cause excessive growth of microorganisms, significantly increase the BOD, and thus, reduce the amount of oxygen dissolved in the fluid and, consequently, cause death of aquatic life through eutrophication (Akpor and Muchie 2011; Dey and Islam 2015; Bassin 2018).

Aerobic and anaerobic biological treatments, chemical precipitation, adsorption, wetlands systems, membrane filtration, electrocoagulation and aerobic granules methods had been successfully used to remove nutrients from wastewaters (Zhang et al. 2009; Bassin 2018; de Oliveira et al. 2018; Khatri et al. 2018; Hermassi et al. 2019; Tian et al. 2018; Yan et al. 2018; Sarvajith et al. 2018; Lyu et al. 2018). Studies also indicated the possible recycling of the nutrients in the form of agricultural fertilizers and generation of biogas through microorganism cultivation (Ummalyma et al. 2018; Mai et al. 2018).

4.10.4 Calcium and Magnesium 
The effluent had slightly lower concentrations of magnesium and calcium. Literature studies, however, indicated reports with values of $1500 \mathrm{mg} \mathrm{L}^{-1}$ of calcium and $889 \mathrm{mg} \mathrm{L}^{-1}$ of magnesium (Table 4). These ions, together with iron, manganese, strontium and others, are responsible for the water hardness characteristic. The hardness directly influences the physical characteristics of the soil and are crucial in the development of plants (Silva et al. 2018). In excess, these ions tend to deteriorate the soil, making it toxic to plants and also to freshwater organisms (Van Dam et al. 2010; Bogart et al. 2019; Qadir et al. 2018). In reused waters, the excess of hardness can clog the pipes and the filter membranes of hydraulic installations (de Araujo and Bezerra 2018; Silva et al. 2018). The techniques of reverse osmosis, membrane filtration, electrocoagulation, carbonization and treatment by aerobic bioreactors were seen to significantly reduce the hardness of wastewaters (Ahn et al. 2018; Cabiguen Jr et al. 2018; Parlar et al. 2018; Singare 2019).

\subsubsection{Cyanide, Organochlorines and Aromatic Hydrocarbons.}

Textile effluents typically contains a large range of organic compounds that may exhibit a certain degree of toxicity. These compounds, with functional groups as phenols, amines, alcohols, ethers, alkanes, are mainly derived from the dye molecules, auxiliary reagents, solvents and organochlorine products used in pest control (Gardiner and Borne 1978; Correia et al. 1994; Ghaly et al. 2014; Castro et al. 2018; Dolez and Benaddi 2018; Liang et al. 2018; Kaur et al. 2019; Sivaram et al. 2019). Fortunately, the sample did not indicate the presence of cyanide, organochlorines and aromatic hydrocarbons, such as chloroform, dichloroethane, trichlorethylene, phenols, benzene, styrene, ethylbenzene, toluene and xylene (Table 2). Other studies, however, detected the presence of those compounds as much as concentrations up to 0.2 and $6.6 \mathrm{mg} \mathrm{L}^{-1}$ of cyanide and phenols (Table 4).

These compounds were seen to cause inhibitory effects on the activity of microorganisms in conventional biological treatments and may be harmful to the environment (Beltrame 2000; Sivaram et al. 2019). Oxidative methods such as the electrochemical, photocatalytic and ozonation have demonstrated success in the removal of organic compounds from textile effluents (Ahmed et al. 2011; Malik et al. 2018; Silva et al. 2018; Kaur et al. 2019). Other removal proposals include the development of new designs of reactors in biological treatments, the use of adapted microorganisms and catalytic enzymes (Husain 2006; Chanwala et al. 2019; Meerbergen et al. 2018; Xu et al. 2018). The substitution of conventional reagents used in textile processing by environmentally friendly compounds is also widely cogitated (Shenai 2001; Kumar and Gunasundari 2018).

Table 4. Maximum concentrations of inorganic and organic components found in different studies with textile effluent $\left(\mathrm{mg} \mathrm{L}^{-1}\right)$.

\begin{tabular}{|c|c|c|c|c|c|c|c|c|c|c|}
\hline Calcium & Magnesium & Chloride & Sodium & Nitrogen & Phosphor & Potassium & Sulphate & Cyanide & Phenols & Reference \\
\hline$<1000$ & 15 & 96 & 227 & 230 & 21 & 355 & 1985 & $<0.010$ & $<0.001$ & Actual study \\
\hline \multirow[t]{2}{*}{ - } & - & - & - & - & - & - & - & 0.20 & 1.10 & Rawlings and \\
\hline & & & & & & & & & & Samfield 1979 \\
\hline
\end{tabular}




\begin{tabular}{|c|c|c|c|c|c|c|c|c|c|c|}
\hline Calcium & Magnesium & Chloride & Sodium & Nitrogen & Phosphor & Potassium & Sulphate & Cyanide & Phenols & Reference \\
\hline - & - & - & - & - & - & - & - & - & 0.00002 & $\begin{array}{l}\text { Castillo et al. } \\
1999\end{array}$ \\
\hline- & - & 2379 & - & - & - & - & - & - & - & Beltrame 2000 \\
\hline- & - & - & - & - & - & - & 345 & 0.20 & 0.077 & $\begin{array}{l}\text { Radetski et al. } \\
2002\end{array}$ \\
\hline- & - & - & 258 & - & 2 & 111 & - & - & - & $\begin{array}{l}\text { Faryal and } \\
\text { Hameed } 2005\end{array}$ \\
\hline 318 & - & 860 & 186 & 246 & - & 9 & 381 & - & - & $\begin{array}{l}\text { Kaushik et al. } \\
2005\end{array}$ \\
\hline - & - & 1820 & - & - & - & - & 680 & - & - & Selcuk 2005 \\
\hline- & - & 34000 & - & - & 2 & - & 30 & - & 6.600 & $\begin{array}{l}\text { Kapdan and } \\
\text { Alparslan } 2005\end{array}$ \\
\hline 1500 & 889 & 2013 & - & - & - & - & 240 & - & 0.143 & $\begin{array}{l}\text { Prasad and Rao } \\
2011\end{array}$ \\
\hline 404 & 210 & 2750 & - & - & - & - & 912 & - & - & Paul et al. 2012 \\
\hline- & - & 98 & - & 10 & 5 & - & 365 & - & 2.620 & $\begin{array}{l}\text { Zaharia and } \\
\text { Suteu } 2013\end{array}$ \\
\hline 15 & 6 & 6 & 4 & - & - & 180 & 119 & - & - & $\begin{array}{l}\text { Manenti et al. } \\
2014\end{array}$ \\
\hline- & 5 & - & 1532 & - & - & - & - & - & - & $\begin{array}{l}\text { Jadhav et al. } \\
2015\end{array}$ \\
\hline - & - & 39 & - & - & - & - & 5 & - & - & Tomei et al. 2016 \\
\hline 8.46 & - & - & - & - & - & - & 5 & - & - & Ajao et al. 2017 \\
\hline - & - & 288 & - & - & - & - & 42 & - & - & Souza et al. 2017 \\
\hline - & - & 506 & - & 21 & 4 & - & 112 & - & - & Silva et al. 2018 \\
\hline 37 & 17 & 844 & 393 & - & 715 & 64 & 430 & - & - & $\begin{array}{l}\text { Sánchez-Sánchez } \\
\text { et al. } 2018\end{array}$ \\
\hline- & - & 1298 & - & 60 & 22 & - & 1118 & - & - & $\begin{array}{l}\text { Sudhanya and } \\
\text { Chinnamma }\end{array}$ \\
\hline
\end{tabular}




\begin{tabular}{|c|c|c|c|c|c|c|c|c|c|c|}
\hline Calcium & Magnesium & Chloride & Sodium & Nitrogen & Phosphor & Potassium & Sulphate & Cyanide & Phenols & Reference \\
\hline & & & & & & & & & & 2018 \\
\hline 110 & 65 & 1382 & 1560 & 29 & 16 & 242 & 310 & - & 0.860 & $\begin{array}{l}\text { Hussain et al. } \\
2018\end{array}$ \\
\hline- & - & - & - & - & - & - & - & - & 0.0000325 & $\begin{array}{l}\text { Castro et al. } \\
2018\end{array}$ \\
\hline- & - & - & - & 89 & 7 & - & - & - & 0.010 & $\begin{array}{l}\text { Chicatto et al. } \\
2018\end{array}$ \\
\hline - & - & 2765 & - & - & - & - & - & 0.090 & - & Singare 2019 \\
\hline
\end{tabular}

\subsection{Heavy Metals and Trace Elements}

Heavy metals are elements with a density greater than $4 \mathrm{~g} / \mathrm{cm}^{3}$, such as cobalt, chromium, copper, iron, manganese, nickel and zinc. Some heavy metals are essential in the development of living organisms, in excess, however, they represent a great environmental risk and are responsible for a variety of health problems (Burakov et al. 2018). Studies indicated that the excess of heavy metals can significantly alter microbial communities, reduce the growth and the development of animals, affect the components and the cellular metabolism, cause damage to organs and nervous systems and persists in the environment for long periods (Akpor and Muchie 2011; Tchounwou et al. 2012; Akpor et al. 2014; Khan and Malik 2018).

The analyses indicated that iron and zinc were the heavy metals in higher concentrations, with values of 0.303 and $0.167 \mathrm{mg} \mathrm{L}^{-1}$ respectively. The other metals detected were chromium, copper, manganese, nickel, tin, as well as traces of aluminum, barium, boron and fluoride (Table 2). Studies in the literature also indicated textile effluents with the presence of arsenic, cadmium, lead and also mercury (Table 5). Most of the heavy metals in textile effluents comes from the constitution of the dye molecules, such as copper and chromium, present in certain types of pigments and metallic dyes (Guaratini and Zanoni 2000; Verma 2008). Other sources include auxiliary reagents used in textile processing, the machinery and the tubulation pipes, herbicides and pesticides, the raw material and the inlet water (Smith 1988; Bisschops and Spanjers 2003).

The main methods used in the removal of heavy metals from wastewater are the chemical precipitation, solvent extraction, membrane filtration, ion exchange, electrochemical removal, coagulation and aerobic granule method (Premkumar et al. 2018; Burakov et al. 2018; Sarma and Tay 2018). In order to reduce the amount of heavy metals generated in the effluent, it is also proposed the substitution of dyes, pigments and conventional additives for eco-friendly products and heavy-metal-free machinery (Smith 1988; Beltrame 2000; Singh and Iyer 2004). 
Table 5. Maximum concentrations of heavy metals and trace elements found in different studies with textile effluents (mg L $\left.{ }^{-1}\right)$.

\begin{tabular}{|c|c|c|c|c|c|c|c|c|c|c|c|c|c|c|c|}
\hline 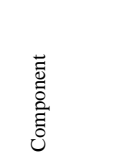 & 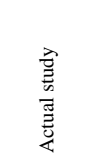 & 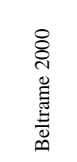 & 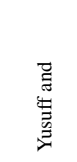 & 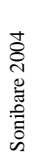 & 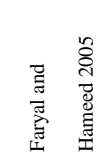 & 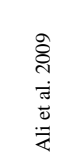 & 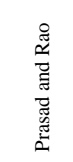 & $\overrightarrow{\text { กี }}$ & 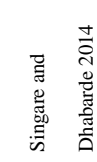 & 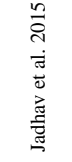 & 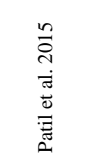 & 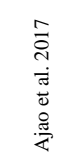 & 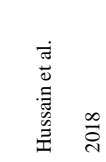 & 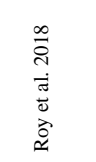 & $\begin{array}{l}\infty \\
\stackrel{0}{1} \\
\text { च } \\
\text { क्च } \\
\dot{0} \\
\frac{0}{4}\end{array}$ \\
\hline Aluminum & 0.104 & - & 0.610 & & - & - & - & & - & - & - & - & 2.500 & - & - \\
\hline Arsenic & $<0.005$ & - & - & & - & - & - & & - & - & - & - & 0.025 & 116.400 & - \\
\hline Barium & 0.025 & - & - & & - & - & - & & - & - & - & - & - & - & 0.075 \\
\hline Boron & 0.125 & - & - & & - & - & - & & - & - & - & - & - & - & 0.021 \\
\hline Cadmium & $<0.001$ & 0.016 & - & & 0.690 & 0.690 & 0.500 & & - & - & - & - & 0.880 & - & - \\
\hline Lead & $<0.005$ & 0.407 & - & & 0.320 & 0.360 & 0.370 & & 2.060 & 0.170 & - & 0.100 & - & 0.173 & - \\
\hline Copper & 0.015 & 0.251 & 5.140 & & 9.700 & 9.730 & 3.620 & & 45.580 & 2.740 & - & 1.096 & - & 0.133 & - \\
\hline Chromium & 0.036 & 1.612 & 0.500 & & 2.140 & 2.200 & 1.500 & & 2.500 & 0.400 & - & 0.061 & 9.700 & 0.749 & 0.004 \\
\hline Tin & 0.013 & 0.285 & - & & - & - & - & & - & - & - & - & - & - & - \\
\hline Iron & 0.303 & 3.889 & 2.140 & & 112.000 & 7.000 & 6.420 & & 55.300 & 0.700 & 1.700 & 8.730 & 14.300 & 0.842 & 0.026 \\
\hline Fluoride & 0.253 & - & - & & - & - & - & & - & - & 12.000 & - & - & - & - \\
\hline Mercury & $<0.0002$ & - & - & & - & - & - & & - & - & - & - & - & - & 0.003 \\
\hline Manganese & 0.045 & - & 1.650 & & 7.400 & 7.530 & 5.400 & & - & 0.470 & - & 1.050 & - & - & 0.010 \\
\hline Nickel & 0.063 & 0.488 & - & & 1.110 & 1.210 & 0.400 & & 2.000 & - & - & - & 7.600 & - & - \\
\hline Silver & $<0.005$ & - & - & & - & - & - & & - & - & & - & - & - & - \\
\hline Selenium & $<0.005$ & - & - & & - & - & - & & - & - & & - & - & - & - \\
\hline Zinc & 0.167 & 0.497 & 0.360 & & 7.870 & 7.850 & 1.000 & & 9.200 & 2.480 & - & 0.201 & - & 0.230 & - \\
\hline
\end{tabular}

\subsection{Ecotoxicological Parameters}

The ecotoxicological results indicated that $D$. magna was the test organism with highest sensitivity towards textile effluent sample, with EC50 value of 3.04\%. The microcrustacean had shown a high degree of sensitivity and demonstrated good reproducibility against different types of pollutants and industrial effluents (Biesinger and Christensen 1972; LeBlanc 1980; Bae and Freeman 2007; Chen et al. 2007). According to table 1, the effluent was classified as very toxic, with 32.9 ATU. Previous reports by Villegas-Navarro et al. (1999) and Forgiarini and Souza (2007) also found textile effluents with high levels of toxicity using this bioindicator, with EC50 values of 3.9 and 8.3\% respectively. Other authors, who used the Daphnia pulex and Artemia salina, reported lethal concentration (LC50) values of 72.0 and 27.6\% respectably (Wells et al. 1994; Souza et al. 2017).

The phytotoxic experiment with $L$. sativa seeds indicated a medium degree of acute toxicity, with EC50 value of $66.24 \%$ and 1.50 ATU (Table 2). The phytotoxic seed germination assay, as previously mentioned by Wang and Keturi (1990), required low cost, simple equipment and mainly, low sampling volume. According to the results, the original textile effluent concentration inhibited about $76 \%$ on L. sativa germination Reports by Phugare et al. (2011) and Bedoui et al. (2015) indicated a total germination inhibition by this kind of effluent using the species Triticum aestivum, Phaseoulus mungo and Lepidium sativum. It was seen by Jadhav et al. (2010) and Alvim et al. (2011) that concentrations up to 10\% of textile effluent was enough to cause genotoxic chromosomal abnormalities in the cells of the roots of Allium 


\section{Macrothink}

cepa onion. Both seed germination and genotoxicity assays were seen to have great importance to access the total ecotoxicity presented by this kind of effluent. Oxidative and biologic methods such as the photocatalytic, ozonation, aerobic and anaerobic degradation, have demonstrated success in reducing the toxicity of textile effluents (De Moraes et al. 2000; Bedoui et al. 2015).

It is important to mention that previous studies have shown that effluents from different stages of textile processing had different levels of ecotoxicity (Villegas-Navarro et al. 2001; Zhang et al. 2012; Liang et al. 2018). Moreover, studies conducted by Wang et al. (2002) indicated that the chemicals used in textile processing also indicated different degrees of acute toxicity. Knowing that the presence of different toxic substances can exhibit unpredictable behavior if combined (Tigini et al. 2010; Charles et al. 2011), it is recommended to treat the effluent in a dedicated manner, as proposed by Correia et al. (1994), that is, a specific treatment for each unit step of the industrial process.

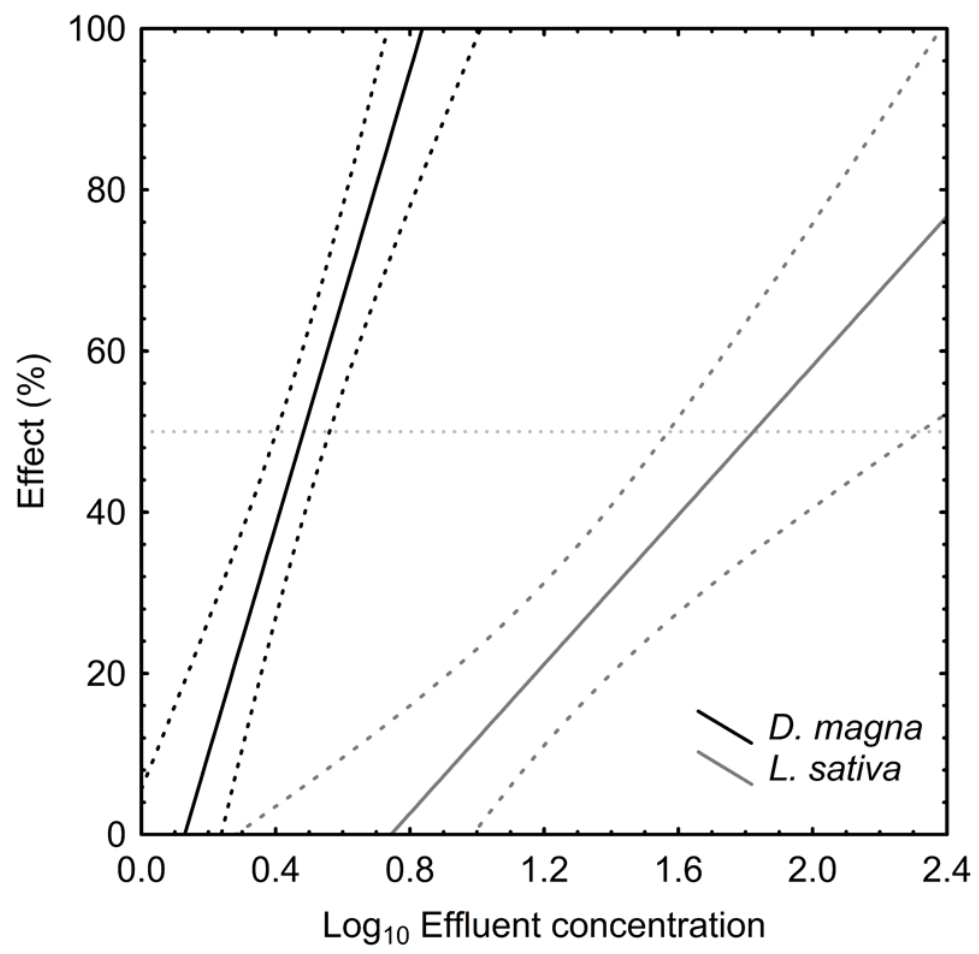

Figure 2. Inhibitory effect of two bioindicators as a function of textile effluent concentration. The bands represent a 95\% interval of confidence.

\section{Conclusion}

It was concluded that textile effluent was alkaline, high colored, with a BOD/COD ratio of 0.49. There were significantly concentrations of oils and greases and great quantities of total solids, mostly composed by dissolved ones. It was detected the presence of heavy metals such as copper, manganese, chromium, tin, iron, nickel, zin and traces of aluminum, barium and boron. There was also the presence of great quantities of chloride, sulphate, sodium, and 
components such as nitrogen, ammoniacal nitrogen, phosphor, potassium, magnesium and fluoride. The analyzes did not indicated the presence of phenols, chloroform and cyanide. The bacteria enumeration indicated the presence of $5.3 \times 10^{5} \mathrm{UFC} \mathrm{mL}^{-1}$ of viable bacteria, 2.0 $\mathrm{x} 10^{2}$ total coliforms and $1.0 \times 10^{2}$ of fecal coliforms. The ecotoxicological analyses indicated a very toxic effluent with $D$. magna (32.9 ATU) and a moderate and toxic degree using $L$. sativa (ATU 1.50).

The parameters analyzed in the study differed considerably to other studies in the literature. The high variation is due to the use of different types of chemical reagents, colorants and raw material. Mixed and integrated systems, which are commonly used in full-scale plants, tend to have better treatment performance. The optimization of the treatment process is considered as a great strategy in reducing the volume and toxicity of textile effluents. Indeed, the dedicated treatment of effluents and optimization of the industrial processes themselves, as well as the development of new machinery and the use of environmentally friendly reagents, are also considered to reduce the pollution generated by this type of industry. From this study, it is expected better estimates related to the development of new methods of textile wastewater treatment, production techniques, and mainly, improvement of well-being and health of employees and consumers.

\section{Acknowledgements}

The author thanks Dra. Aparecida Marin-Morales (Universidade Estadual Paulista - UNESP) for her kindful support, friendship and charity. The study was financed in part by the Coordenação de Aperfeiçoamento de Pessoal de Nível Superior - Brasil (CAPES) - Finance Code 001.

\section{References}

Abo-Elela, S. I., El-Gohary, F. A., Ali, H. I., \& Wahaab, R. S. A. (1988). Treatability studies of textile wastewater. Environmental Technology, 9(2), 101-108. https://doi.org/10.1080/09593338809384546

Agarwal, V., Kaur, R., \& De, D. (2017). Scenario Analysis of Textile Industry in Asia-Pacific Trade Agreement (APTA). Procedia computer science, 122, 685-690. https://doi.org/10.1016/j.procs.2017.11.424

Ahmed, S., Rasul, M. G., Martens, W. N., Brown, R., \& Hashib, M. A. (2011). Advances in heterogeneous photocatalytic degradation of phenols and dyes in wastewater: a review. Water, Air, \& Soil Pollution, 215(1-4), 3-29. https://doi.org/10.1007/s11270-010-0456-3

Ahn, M., Chilakala, R., Han, C., \& Thenepalli, T. (2018). Removal of Hardness from Water Samples by a Carbonation Process with a Closed Pressure Reactor. Water, 10(1), 54. https://doi.org/10.3390/w10010054

Ajao, A. T., Adebayo, G. B., \& Yakubu, S. E. (2017). Bioremediation of Textile Industrial Effluent using mixed culture of Pseudomonas aeruginosa and Bacillus subtilis immobilized on agaragar in a Bioreactor. Journal of microbiology and biotechnology research, 1(3), 50-56. 
Akpor, O. B., \& Muchie, B. (2011). Environmental and public health implications of wastewater quality. African Journal of Biotechnology, 10(13), 2379-2387.

Akpor, O. B., Ohiobor, G. O., \& Olaolu, T. D. (2014). Heavy metal pollutants in wastewater effluents: sources, effects and remediation. Advances in Bioscience and Bioengineering, 2(4), 37-43.

Ali, N., Hameed, A., \& Ahmed, S. (2009). Physicochemical characterization and bioremediation perspective of textile effluent, dyes and metals by indigenous bacteria. Journal of hazardous materials, 322-328. https://doi.org/10.1016/j.jhazmat.2008.08.006

Al-Kdasi, A., Idris, A., Saed, K., \& Guan, C. T. (2004). Treatment of textile wastewater by advanced oxidation processes—a review. Global nest: The Int. J, 6(3), 222-230.

Alvim, L. B., Kummrow, F., Beijo, L. A., de Andrade Lima, C. A., \& Barbosa, S. (2011). Avaliação da citogenotoxicidade de efluentes têxteis utilizando Allium cepa L. Revista Ambiente e Água, 6(2).

Amabilis-Sosa, L., Vázquez-López, M., Rojas, J., Roé-Sosa, A., \& Moeller-Chávez, G. (2018). Efficient Bacteria Inactivation by Ultrasound in Municipal Wastewater. Environments, 5(4), 47. https://doi.org/10.3390/environments5040047

American Public Health Association - APHA. (2017). Standard method for examination of water and wastewater, 23 ed. Washington, DC.

Aquino, J. M., Pereira, G. F., Rocha-Filho, R. C., Bocchi, N., \& Biaggio, S. R. (2016). Combined coagulation and electrochemical process to treat and detoxify a real textile effluent. Water, Air, \& Soil Pollution, 227(8), 266. https://doi.org/10.1007/s11270-016-2967-z

Araújo, A. S. F., \& Monteiro, R. T. R. (2005). Plant bioassays to assess toxicity of textile sludge compost. Scientia Agricola, 62(3), 286-290. http://dx.doi.org/10.1590/S0103-90162005000300013

Asghar, M. Z. (2018). Comparative assessment of physico-chemical parameters of waste water effluents from different industries in Lahore, Pakistan. Proceedings of the International Academy of Ecology and Environmental Sciences, 8(2), 99.

Bae, J. S., \& Freeman, H. S. (2007). Aquatic toxicity evaluation of new direct dyes to the Daphnia magna. Dyes and Pigments, 73(1), 81-85. https://doi.org/10.1016/j.dyepig.2005.10.015

Bassin, J. P. (2018). New processes for biological nitrogen removal. In Advanced Biological Processes for Wastewater Treatment (pp. 143-203). Springer, Cham. https://doi.org/10.1007/978-3-319-58835-3_5

Bedoui, A., Tigini, V., Ghedira, K., Varese, G. C., \& Ghedira, L. C. (2015). Evaluation of an eventual ecotoxicity induced by textile effluents using a battery of biotests. Environmental Science and Pollution Research, 22(21), 16700-16708. 
https://doi.org/10.1007/s11356-015-4862-3

Beltrame, L. T. C. (2000). Caracterização de efluente têxtil e proposta de tratamento (Master's thesis, Universidade Federal do Rio Grande do Norte).

Bes-Piá, A., Iborra-Clar, M. I., Iborra-Clar, A., Mendoza-Roca, J. A., Cuartas-Uribe, B., \& Alcaina-Miranda, M. I. (2005). Nanofiltration of textile industry wastewater using a physicochemical process as a pre-treatment. Desalination, 178(1-3), 343-349. https://doi.org/10.1016/j.desal.2004.11.044

Bhattacharjee, S. (2017). Removal of biological organic matter and suspended solid from textile wastewater using anaerobic-aerobic process: A review of an industrial implementation. Journal of Scientific Research, 9(2), 267-275. https://doi.org/10.3329/jsr.v9i2.31302

Biesinger, K. E., \& Christensen, G. M. (1972). Effects of various metals on survival, growth, reproduction, and metabolism of Daphnia magna. Journal of the Fisheries Board of Canada, 29(12), 1691-1700. https://doi.org/10.1139/f72-269

Bisschops, I., \& Spanjers, H. (2003). Literature review on textile wastewater characterisation. Environmental technology, 24(11), 1399-1411. https://doi.org/10.1080/09593330309385684

Bogart, S. J., Azizishirazi, A., \& Pyle, G. G. (2019). Challenges and future prospects for developing $\mathrm{Ca}$ and $\mathrm{Mg}$ water quality guidelines: a meta-analysis. Phil. Trans. R. Soc. B, 374(1764) (2018)0364. https://doi.org/10.1098/rstb.2018.0364

Bouaouine, O., Baudu, M., Khalil, F., Chtioui, H., \& Zaitan, H. (2017). Comparative study between Moroccan cactus and chemicals coagulants for textile effluent treatment. J Mater Environ Sci, 8, 2687-2693.

Burakov, A. E., Galunin, E. V., Burakova, I. V., Kucherova, A. E., Agarwal, S., Tkachev, A. G., \& Gupta, V. K. (2018). Adsorption of heavy metals on conventional and nanostructured materials for wastewater treatment purposes: A review. Ecotoxicology and environmental safety, 148, 702-712. https://doi.org/10.1016/j.ecoenv.2017.11.034

Cabiguen Jr, M. L., Soriano, A. N., \& Adornado, A. P. (2018). Reduction of water hardness from groundwater in Puerto Princesa City, Palawan, Philippines using electrocoagulation. In IOP Conference Series: Earth and Environmental Science (Vol. 191, No. 1, p. 012029).

Cardoso, J. C., Bessegato, G. G., \& Zanoni, M. V. B. (2016). Efficiency comparison of ozonation, photolysis, photocatalysis and photoelectrocatalysis methods in real textile wastewater decolorization. Water research, 98, 39-46. https://doi.org/10.1016/j.watres.2016.04.004

Carmen, Z., \& Daniela, S. (2012). February. Textile organic dyes-characteristics, polluting effects and separation/elimination procedures from industrial effluents-a critical overview. In Organic pollutants ten years after the Stockholm convention-environmental and analytical update. IntechOpen.

Castillo, M., Barcelo, D., Pereira, A. S., \& Neto, F. A. (1999). Characterization of organic 
pollutants in industrial effluents by high-temperature gas chromatography-mass spectrometry. TrAC Trends in Analytical Chemistry, 18(1), 26-36. https://doi.org/10.1016/S0165-9936(98)00066-1

Castro, M., Nogueira, V., Lopes, I., Vieira, M. N., Rocha-Santos, T., \& Pereira, R. (2018). Treatment of a textile effluent by adsorption with cork granules and titanium dioxide nanomaterial. Journal of Environmental Science and Health, Part A, 53(6), 524-536. https://doi.org/10.1080/10934529.2018.1425020

Chandanshive, V. V., Rane, N. R., Tamboli, A. S., Gholave, A. R., Khandare, R. V., \& Govindwar, S. P. (2017). Co-plantation of aquatic macrophytes Typha angustifolia and Paspalum scrobiculatum for effective treatment of textile industry effluent. Journal of hazardous materials, 338, 47-56. https://doi.org/10.1016/j.jhazmat.2017.05.021

Chandran, D. (2016). A review of the textile industries waste water treatment methodologies. Int J Sci Eng Res, 7, 392-403.

Chanwala, J., Kaushik, G., Dar, M. A., Upadhyay, S., \& Agrawal, A. (2019). Process optimization and enhanced decolorization of textile effluent by Planococcus sp. isolated from textile sludge. Environmental Technology \& Innovation, 13, 122-129. https://doi.org/10.1016/j.eti.2018.11.008

Charles, J., Sancey, B., Morin-Crini, N., Badot, P. M., Degiorgi, F., Trunfio, G., \& Crini, G. (2011). Evaluation of the phytotoxicity of polycontaminated industrial effluents using the lettuce plant (Lactuca sativa) as a bioindicator. Ecotoxicology and environmental safety, 74(7), 2057-2064. https://doi.org/10.1016/j.ecoenv.2011.07.025

Chen, C. Y., Ko, C. W., \& Lee, P. I. (2007). Toxicity of substituted anilines to Pseudokirchneriella subcapitata and quantitative structure-activity relationship analysis for polar narcotics. Environmental toxicology and chemistry, 26(6), 1158-1164.

Chen, G. (2004). Electrochemical technologies in wastewater treatment. Separation and purification Technology, 38(1), 11-41. https://doi.org/10.1016/j.seppur.2003.10.006

Chicatto, J. A., Nunes, H. C. A., Gonçalves, M. J., Helm, C. V., Altmajer Vaz, D., \& Tavares, L. B. B. (2018). Strategies for decolorization of textile industry effluents by white rot fungi with peach palm residue. Embrapa Florestas-Artigo em periódico indexado (ALICE).

Choo, K. H., Choi, S. J., \& Hwang, E. D. (2007). Effect of coagulant types on textile wastewater reclamation in a combined coagulation/ultrafiltration system. Desalination, 202(1-3), 262-270. https://doi.org/10.1016/j.desal.2005.12.063

Chuang, S. H., Chang, T. C., Ouyang, C. F., \& Leu, J. M. (2007). Colloidal silica removal in coagulation processes for wastewater reuse in a high-tech industrial park. Water science and technology, 55(1-2), 187-195. https://doi.org/10.2166/wst.2007.054

Ciardelli, G., Corsi, L., \& Marcucci, M. (2001). Membrane separation for wastewater reuse in the textile industry. Resources, conservation and recycling, 31(2), 189-197. https://doi.org/10.1016/S0921-3449(00)00079-3 
Clément, B., \& Merlin, G. (1995). The contribution of ammonia and alkalinity to landfill leachate toxicity to duckweed. Science of the Total Environment, 170(1-2), 71-79. https://doi.org/10.1016/0048-9697(95)04563-G

Correia, V. M., Stephenson, T., \& Judd, S. J. (1994). Characterisation of textile wastewaters-a $\begin{array}{llll}\text { review. Environmental } & \text { 15(10), }\end{array}$ https://doi.org/10.1080/09593339409385500

Costa, C. R., Olivi, P., Botta, C. M., \& Espindola, E. L. (2008). A toxicidade em ambientes aquáticos: discussão e métodos de avaliação. Química Nova, 31(7), 1820-1830.

Damodaran, R. et al. (2017). Isolation, identification and resistant characterization of dye-adapted bacteria from Tirupur textile effluent. World journal of pharmacy and pharmaceutical sciences, 6(9), 1111-1125. https://doi.org/ 10.20959/wjpps20179-9973

Das, M., Ahmed, M. K., Begum, F., Parveen, S., Islam, M. M., \& Begum, M. (2010). Microbial load in tannery and textile effluents and their receiving rivers of Dhaka. Dhaka University Journal of Biological Sciences, $19(1), \quad 73-81$. https://doi.org/10.3329/dujbs.v19i1.8946

Dasgupta, J., Sikder, J., Chakraborty, S., Curcio, S., \& Drioli, E. (2015). Remediation of textile effluents by membrane based treatment techniques: a state of the art review. Journal of environmental management, 147, 55-72.

de Araujo, C. S. P., \& Bezerra, J. M. (2018). Qualidade das águas subterrâneas da cidade de pau dos Ferros-RN. Revista Geotemas, 8(2), 116-131. https://doi.org/10.33237/geotemas.v8i2.3196

De la Obra Jímenez, I., García, B. E., Ibañez, G. R., López, J. C., \& Perez, J. S. (2019). Continuous flow disinfection of WWTP secondary effluents by solar photo-Fenton at neutral $\mathrm{pH}$ in raceway pond reactors at pilot plant scale. Applied Catalysis B: Environmental. https://doi.org/10.1016/j.apcatb.2019.01.093

de la Torre-González, A., Montesinos-Pereira, D., Romero, L., Blasco, B., \& Ruiz, J. M. (2018). Analysis of metabolic and nutritional biomarkers in Brassica oleracea L. cv. Bronco plants under alkaline stress. The Journal of Horticultural Science and Biotechnology, 93(3), 279-288. https://doi.org/10.1080/14620316.2017.1364979

De Moraes, S. G., Freire, R. S., \& Duran, N. (2000). Degradation and toxicity reduction of textile effluent by combined photocatalytic and ozonation processes. Chemosphere, 40(4), 369-373. https://doi.org/10.1016/S0045-6535(99)00239-8

de Oliveira, T. S., Corsino, S. F., Di Trapani, D., Torregrossa, M., \& Viviani, G. (2018). Biological minimization of excess sludge in a membrane bioreactor: Effect of plant configuration on sludge production, nutrient removal efficiency and membrane fouling $\begin{array}{llll}\text { tendency. } \quad \text { Bioresource } & \text { 146-155. }\end{array}$ https://doi.org/10.1016/j.biortech.2018.03.035

Dey, S., \& Islam, A. (2015). A review on textile wastewater characterization in Bangladesh. 
Resources and Environment, 5(1), 15-44.

Dolez, P. I., \& Benaddi, H. (2018). Toxicity testing of textiles. In Advanced Characterization and Testing of Textiles (pp. 151-188). Woodhead Publishing. https://doi.org/10.1016/B978-0-08-100453-1.00008-8

dos Santos, R. F., Ramlow, H., Dolzan, N., Machado, R. A. F., de Aguiar, C. R. L., \& Marangoni, C. (2018). Influence of different textile fibers on characterization of dyeing wastewater and final effluent. Environmental monitoring and assessment, 190(11), 693. https://doi.org/10.1007/s10661-018-7068-6

El-Bestawy, E., El-Masry, M. H., \& Nawal, E. (2005). The potentiality of free Gram-negative bacteria for removing oil and grease from contaminated industrial effluents. World Journal of Microbiology and Biotechnology, 21(6-7), 815-822. https://doi.org/10.1007/s11274-004-2239-8

Faryal, R. A. N. I., \& Hameed, A. (2005). Isolation and characterization of various fungal strains from textile effluent for their use in bioremediation. Pakistan Journal of Botany, 37(4), 1003.

Favas, P. J. C., Sarkar, S. K., Rakshit, D., Venkatachalam, P., \& Prasad, M. N. V. (2016). Acid mine drainages from abandoned mines: hydrochemistry, environmental impact, resource recovery, and prevention of pollution. In Environmental Materials and Waste (pp. 413-462). Academic Press. https://doi.org/10.1016/B978-0-12-803837-6.00017-2

Favero, B. M., Favero, A. C., Taffarel, S. R., \& Souza, F. S. (2018). Evaluation of the efficiency of coagulation/flocculation and Fenton process in reduction of colour, turbidity and COD of a textile effluent. Environmental technology, 1-10. https://doi.org/10.1080/09593330.2018.1542035

Fersi, C., Gzara, L., \& Dhahbi, M. (2005). Treatment of textile effluents by membrane technologies. Desalination, 185(1-3), 399-409.

Flowers, T. J., Munns, R., \& Colmer, T. D. (2014). Sodium chloride toxicity and the cellular basis of salt tolerance in halophytes. Annals of botany, 115(3), 419-431. https://doi.org/10.1016/j.desal.2005.03.087

Forgiarini, E., \& de Souza, A. A. U. (2007). Toxicity of textile dyes and their degradation by the enzyme horseradish peroxidase (HRP). Journal of Hazardous Materials, 147(3), 1073-1078. https://doi.org/10.1016/j.jhazmat.2007.06.003

Gardiner, D. K., \& Borne, B. J. (1978). Textile waste waters: treatment and environmental effects. Journal of the Society of Dyers and Colourists, 94(8), 339-348. https://doi.org/10.1111/j.1478-4408.1978.tb03420.x

Gavrilescu, M. (2010). Environmental biotechnology: achievements, opportunities and challenges. Dynamic biochemistry, process biotechnology and molecular biology, 4(1), 1-36.

Gavrilescu, M., Demnerová, K., Aamand, J., Agathos, S., \& Fava, F. (2015). Emerging 
pollutants in the environment: present and future challenges in biomonitoring, ecological risks and bioremediation. New biotechnology, 32(1), 147-156. https://doi.org/10.1016/j.nbt.2014.01.001

Geilfus, C. M., Ludwig-Müller, J., Bárdos, G., \& Zörb, C. (2018). Early response to salt ions in maize (Zea mays L.). Journal of plant physiology, 220, 173-180. https://doi.org/10.1016/j.jplph.2017.11.010

Ghaly, A. E., Ananthashankar, R., Alhattab, M. V. V. R., \& Ramakrishnan, V. V. (2014). Production, characterization and treatment of textile effluents: a critical review. J Chem Eng Process Technol, 5(1), 1-19.

GilPavas, E., Dobrosz-Gómez, I., \& Gómez-García, M. Á. (2018). Optimization of sequential chemical coagulation-electro-oxidation process for the treatment of an industrial textile $\begin{array}{lllll}\text { wastewater. Journal of water process engineering, 22, } & 73-79 .\end{array}$ https://doi.org/10.1016/j.jwpe.2018.01.005

Giwa, A., \& Ogunribido, A. (2012). The applications of membrane operations in the textile industry: a review. British Journal of Applied Science \& Technology, 2(3), p.296.

Gökkuş, Ö., Yıldız, N., Koparal, A. S., \& Yıldız, Y. Ş. (2018). Evaluation of the effect of oxygen on electro-Fenton treatment performance for real textile wastewater using the Taguchi approach. International journal of environmental science and technology, 15(2), 449-460. https://doi.org/10.1007/s13762-017-1404-1

Gomes, J., Frasson, D., Quinta-Ferreira, R. M., Matos, A., \& Martins, R. C. (2019). Removal of Enteric Pathogens from Real Wastewater Using Single and Catalytic Ozonation. Water, 11(1), 127. https://doi.org/10.3390/w11010127

Gómez, R., Arce, M. I., Baldwin, D. S., \& Dahm, C. N. (2017). Water physicochemistry in intermittent rivers and ephemeral streams. In Intermittent Rivers and Ephemeral Streams (pp. 109-134). Academic Press. https://doi.org/10.1016/B978-0-12-803835-2.00005-X

Goodfellow, W. L., Ausley, L. W., Burton, D. T., Denton, D. L., Dorn, P. B., Grothe, D. R., ... \& Rodgers, J. H. (2000). Major ion toxicity in effluents: A review with permitting recommendations. Environmental Toxicology and Chemistry, 19(1), 175-182.

Goodwin, S., Conrad, R., \& Zeikus, J. G. (1988). Influence of $\mathrm{pH}$ on microbial hydrogen metabolism in diverse sedimentary ecosystems. Appl. Environ. Microbiol., 54(2), 590-593.

Greenlee, L. F., Lawler, D. F., Freeman, B. D., Marrot, B., \& Moulin, P. (2009). Reverse osmosis desalination: water sources, technology, and today's challenges. Water research, 43(9), 2317-2348. https://doi.org/10.1016/j.watres.2009.03.010

Guaratini, C. C., \& Zanoni, M. V. B. (2000). Corantes têxteis. Química nova, 71-78.

Hamid, N. S. A. A., Malek, N. A. C., Mokhtar, H., Mazlan, W. S., \& Tajuddin, R. M. (2016). Removal of oil and grease from wastewater using natural adsorbents. Jurnal Teknologi, 78(5-3). 
Hartman, W. H., Richardson, C. J., Vilgalys, R., \& Bruland, G. L. (2008). Environmental and anthropogenic controls over bacterial communities in wetland soils. Proceedings of the National Academy of Sciences, 105(46), 17842-17847.

Hassan, M. M., Alam, M. Z., \& Anwar, M. N. (2013). Biodegradation of textile azo dyes by bacteria isolated from dyeing industry effluent. Int Res J Biol Sci, 2(8), 27-31.

Herigstad, B., Hamilton, M., \& Heersink, J. (2001). How to optimize the drop plate method for enumerating bacteria. Journal of microbiological methods, 44(2), 121-129. https://doi.org/10.1016/S0167-7012(00)00241-4

Hermassi, M., Guaya, D., Gibert, O., Valderrama, C., \& Cortina, J. L. (2019). Valorisation of Nutrients in Wastewaters Using Reactive Inorganic Sorbents. In Phosphorus Recovery and Recycling (pp. 457-482). Springer, Singapore. https://doi.org/10.1007/978-981-10-8031-9_32

Hirn, J. (1980). Indicator bacteria and Salmonella in food-processing and domestic effluent. Journal (Water Pollution Control Federation), pp.48-52.

Hoffman, D. J., Rattner, B. A., Burton Jr, G. A., \& Cairns Jr, J. (Eds.). (2002). Handbook of ecotoxicology. CRC press.

Holkar, C. R., Jadhav, A. J., Pinjari, D. V., Mahamuni, N. M., \& Pandit, A. B. (2016). A critical review on textile wastewater treatments: possible approaches. Journal of environmental management, 182, 351-366. https://doi.org/10.1016/j.jenvman.2016.07.090

Hongve, D., \& Åkesson, G. (1996). Spectrophotometric determination of water colour in $\begin{array}{llll}\text { Hazen } \quad \text { Wnits. } & \text { 2771-2775. }\end{array}$ https://doi.org/10.1016/S0043-1354(96)00163-7

Husain, Q. (2006). Potential applications of the oxidoreductive enzymes in the decolorization and detoxification of textile and other synthetic dyes from polluted water: a review. Critical reviews in biotechnology, 26(4), 201-221. https://doi.org/10.1080/07388550600969936

Hussain, T., \& Wahab, A. (2018). A critical review of the current water conservation practices in textile wet processing. Journal of Cleaner Production. https://doi.org/10.1016/j.jclepro.2018.07.051

Hussain, Z., Arslan, M., Malik, M. H., Mohsin, M., Iqbal, S., \& Afzal, M. (2018). Integrated perspectives on the use of bacterial endophytes in horizontal flow constructed wetlands for the treatment of liquid textile effluent: phytoremediation advances in the field. Journal of environmental management, 224, 387-395.

Iqbal, M., \& Nisar, J. (2015). Cytotoxicity and mutagenicity evaluation of gamma radiation and hydrogen peroxide treated textile effluents using bioassays. Journal of Environmental Chemical Engineering, 3(3), 1912-1917. https://doi.org/10.1016/j.jenvman.2018.07.057

Islam, M. I., Mehedy, M. E., Chowdhury, S., Sen, P., Shormi, H. J., \& Biswas, M. (2015). Physicochemical analysis of textile dye effluent and screening the textile dye degrading microbial species. IOSR Journal of Environmental Science, Toxicology and Food Technology, 
9(3), 51-55.

Jadhav, J. P., Kalyani, D. C., Telke, A. A., Phugare, S. S., \& Govindwar, S. P. (2010). Evaluation of the efficacy of a bacterial consortium for the removal of color, reduction of heavy metals, and toxicity from textile dye effluent. Bioresource Technology, 101(1), 165-173. https://doi.org/10.1016/j.biortech.2009.08.027

Jadhav, S. B., Chougule, A. S., Shah, D. P., Pereira, C. S., \& Jadhav, J. P. (2015). Application of response surface methodology for the optimization of textile effluent biodecolorization and its toxicity perspectives using plant toxicity, plasmid nicking assays. Clean Technologies and Environmental Policy, 17(3), 709-720. https://doi.org/10.1007/s10098-014-0827-3

Janani, S., \& Kumar, S. S. (2018). Performance analysis of different textile effluent treatment processes involving marine diatom Odontella aurita. Environmental Technology \& Innovation, 11, 153-164. https://doi.org/10.1016/j.eti.2018.06.002

Jayaseelan, T., Damodaran, R., Ganesan, S., \& Mani, P. (2018). Biochemical characterization and 16s rRNA sequencing of different bacteria from textile dye effluents. Journal of Drug Delivery and Therapeutics, 8(6), 35-40. https://doi.org/10.22270/jddt.v8i6.2004

Jorfi, S., Barzegar, G., Ahmadi, M., Soltani, R. D. C., Takdastan, A., Saeedi, R., \& Abtahi, M. (2016). Enhanced coagulation-photocatalytic treatment of Acid red 73 dye and real textile wastewater using UVA/synthesized MgO nanoparticles. Journal of environmental management, 177, 111-118. https://doi.org/10.1016/j.jenvman.2016.04.005

Kapdan, I. K., \& Alparslan, S. (2005). Application of anaerobic-aerobic sequential treatment system to real textile wastewater for color and COD removal. Enzyme and Microbial Technology, 36(2-3), 273-279. https://doi.org/10.1016/j.enzmictec.2004.08.040

Kaur, P., Sangal, V. K., \& Kushwaha, J. P. (2019). Parametric study of electro-Fenton treatment for real textile wastewater, disposal study and its cost analysis. International Journal of Environmental Science and Technology, 16(2), 801-810. https://doi.org/10.1007/s13762-018-1696-9

Kaushik, P., Garg, V. K., \& Singh, B. (2005). Effect of textile effluents on growth performance of wheat cultivars. Bioresource technology, 96(10), 1189-1193. https://doi.org/10.1016/j.biortech.2004.09.020

Khan, S., \& Malik, A. (2018). Toxicity evaluation of textile effluents and role of native soil bacterium in biodegradation of a textile dye. Environmental Science and Pollution Research, 25(5), 4446-4458. https://doi.org/10.1007/s11356-017-0783-7

Khatri, A., Peerzada, M. H., Mohsin, M., \& White, M. (2015). A review on developments in dyeing cotton fabrics with reactive dyes for reducing effluent pollution. Journal of Cleaner Production, 87, 50-57. https://doi.org/10.1016/j.jclepro.2014.09.017

Khatri, J., Nidheesh, P. V., Singh, T. A., \& Kumar, M. S. (2018). Advanced oxidation processes based on zero-valent aluminium for treating textile wastewater. Chemical Engineering Journal, 348, 67-73. https://doi.org/10.1016/j.cej.2018.04.074 
Kolhe, A. S., \& Pawar, V. P. (2011). Physico-chemical analysis of effluents from dairy industry. Recent Research in Science and Technology, 3(5).

Kozlowski, A., Searcy, C., \& Bardecki, M. (2016). Innovation for a sustainable fashion industry: a design focused approach toward the development of new business models. In Green Fashion (pp. 151-169). Springer, Singapore. https://doi.org/10.1007/978-981-10-0245-8_5

Kumar, P. S., \& Gunasundari, E. (2018). Green Chemistry in Textiles. In Sustainable Innovations in Textile Chemistry and Dyes (pp. 53-73). Springer, Singapore. https://doi.org/10.1007/978-981-10-8600-7_3

Kumar, P. S., Narayan, A. S., \& Dutta, A. (2017). Nanochemicals and Effluent Treatment in Textile Industries. In Textiles and Clothing Sustainability (pp. 57-96). Springer, Singapore. https://doi.org/10.1007/978-981-10-2188-6_2

Kunz, A., Peralta-Zamora, P., Moraes, S. G. D., \& Durán, N. (2002). Novas tendências no tratamento de efluentes têxteis. Química nova.

Lacoul, P., \& Freedman, B. (2006). Environmental influences on aquatic plants in freshwater ecosystems. Environmental Reviews, 14(2), 89-136. https://doi.org/10.1139/a06-001

Lafi, R., Gzara, L., Lajimi, R. H., \& Hafiane, A. (2018). Treatment of textile wastewater by a hybrid ultrafiltration/electrodialysis process. Chemical Engineering and Processing-Process Intensification, 132, 105-113. https://doi.org/10.1016/j.cep.2018.08.010

LeBlanc, G. A. (1980). Acute toxicity of priority pollutants to water flea (Daphnia magna). Bulletin of environmental contamination and toxicology, 24(1), 684-691. https://doi.org/10.1007/BF01608174

Lee, K. E., Morad, N., Teng, T. T., \& Poh, B. T. (2012). Development, characterization and the application of hybrid materials in coagulation/flocculation of wastewater: A review. Chemical Engineering Journal, 203, 370-386. https://doi.org/10.1016/j.cej.2012.06.109

Leson, G., \& Winer, A. M. (1991). Biofiltration: an innovative air pollution control technology for VOC emissions. Journal of the Air \& Waste Management Association, 41(8), 1045-1054. https://doi.org/10.1080/10473289.1991.10466898

Levin, S. A., Harwell, M. A., Kelly, J. R., \& Kimball, K. D. (2011). Ecotoxicology: problems and approaches. In Ecotoxicology: Problems and Approaches (pp. 3-7). Springer, New York, NY. https://doi.org/10.1007/978-1-4612-3520-0_1

Liang, J., Ning, X. A., Sun, J., Song, J., Lu, J., Cai, H., \& Hong, Y. (2018). Toxicity evaluation of textile dyeing effluent and its possible relationship with chemical oxygen demand. Ecotoxicology and environmental safety, 166, 56-62. https://doi.org/10.1016/j.ecoenv.2018.08.106

Lin, S. H., \& Peng, C. F. (1994). Treatment of textile wastewater by electrochemical method. Water research, 28(2), 277-282. https://doi.org/10.1016/0043-1354(94)90264-X 
Lucato, W. C., Costa, E. M., \& de Oliveira Neto, G. C. (2017). The environmental performance of SMEs in the Brazilian textile industry and the relationship with their financial performance. Journal of environmental management, 203, 550-556. https://doi.org/10.1016/j.jenvman.2017.06.028

Lyu, T., He, K., Dong, R., \& Wu, S. (2018). The intensified constructed wetlands are promising for treatment of ammonia stripped effluent: Nitrogen transformations and removal $\begin{array}{llll}\text { pathways. Environmental 273-282. } & \text { Pollution, 236, }\end{array}$ https://doi.org/10.1016/j.envpol.2018.01.056

Mahbub, K. R., Mohammad, A., Ahmed, M. M., \& Begum, S. (2012). Decolorization of synthetic dyes using bacteria isolated from textile industry effluent. Asian journal of biotechnology, 4(3), 129-136. https://doi.org/10.3923/ajbkr.2012.129.136

Mai, D. T., Kunacheva, C., \& Stuckey, D. C. (2018). A review of posttreatment technologies for anaerobic effluents for discharge and recycling of wastewater. Critical reviews in environmental science and technology, 48(2), 167-209. https://doi.org/10.1080/10643389.2018.1443667

Malik, S. N., Ghosh, P. C., Vaidya, A. N., \& Mudliar, S. N. (2018). Catalytic ozone pretreatment of complex textile effluent using $\mathrm{Fe} 2+$ and zero valent iron nanoparticles. Journal of hazardous materials, 357, 363-375. https://doi.org/10.1016/j.jhazmat.2018.05.070

Manenti, D. R., Módenes, A. N., Soares, P. A., Espinoza-Quiñones, F. R., Boaventura, R. A., Bergamasco, R., \& Vilar, V. J. (2014). Assessment of a multistage system based on electrocoagulation, solar photo-Fenton and biological oxidation processes for real textile wastewater treatment. Chemical Engineering Journal, 252, 120-130. https://doi.org/10.1016/j.cej.2014.04.096

Meerbergen, K., Willems, K. A., Dewil, R., Van Impe, J., Appels, L., \& Lievens, B. (2018). Isolation and screening of bacterial isolates from wastewater treatment plants to decolorize azo dyes. Journal of bioscience and bioengineering, 125(4), 448-456. https://doi.org/10.1016/j.jbiosc.2017.11.008

Moriarty, F. (1988). Ecotoxicology. Human toxicology, 7(5), 437-441. https://doi.org/10.1177\%2F096032718800700510

Morrison, G., Fatoki, O. S., Persson, L., \& Ekberg, A. (2001). Assessment of the impact of point source pollution from the Keiskammahoek Sewage Treatment Plant on the Keiskamma River-pH, electrical conductivity, oxygen-demanding substance (COD) and nutrients. Water Sa, 27(4), 475-480. http://dx.doi.org/10.4314/wsa.v27i4.4960

Müezzinoğlu, A. (1998). Air pollutant emission potentials of cotton textile manufacturing $\begin{array}{llll}\text { industry. Journal of Cleaner } & \text { 339-347. }\end{array}$ https://doi.org/10.1016/S0959-6526(98)00013-4

Nawaz, M. S., \& Ahsan, M. (2014). Comparison of physico-chemical, advanced oxidation and biological techniques for the textile wastewater treatment. Alexandria Engineering 
Journal, 53(3), 717-722. https://doi.org/10.1016/j.aej.2014.06.007

O’Neill, C., Hawkes, F. R., Hawkes, D. L., Lourenço, N. D., Pinheiro, H. M., \& Delée, W. (1999). Colour in textile effluents-sources, measurement, discharge consents and simulation: a review. Journal of Chemical Technology \& Biotechnology: International Research in Process, Environmental \& Clean Technology, 74(11), 1009-1018. https://doi.org/10.1002/(SICI)1097-4660(199911)74:11\%3C1009::AID-JCTB153\%3E3.0.CO ;2-N

Ogunlaja, O. O., \& Aemere, O. (2009). Evaluating the efficiency of a textile wastewater treatment plant located in Oshodi, Lagos. African Journal of Pure and Applied Chemistry, 3(10), 189-196.

Organization for Economic Co-operation and Development - OECD. (2004). Test No. 202: Guideline for the testing of chemicals Daphnia sp. acute immobilization test, Paris.

Pal, P. (2014). Detection of coliforms in drinking water and its effect on human health-A review. International Letters of Natural Sciences, 12(2).

Parlar, I., Hacıfazlığlu, M., Kabay, N., Pek, T. Ö., \& Yüksel, M. (2018). Performance comparison of reverse osmosis (RO) with integrated nanofiltration (NF) and reverse osmosis process for desalination of MBR effluent. Journal of Water Process Engineering. https://doi.org/10.1016/j.jwpe.2018.06.002

Patil, P., Patil, V., Surwase, S., \& Jadhav, J. (2015). Evaluation of the efficiency of isolated bacterial consortium PMB11 in removal of colour, degradation and reduction of toxicity from textile dye effluent. Biologia, 70(1), 11-18. https://doi.org/10.1515/biolog-2015-0008

Paul, S. A., Chavan, S. K., \& Khambe, S. D. (2012). Studies on characterization of textile industrial waste water in Solapur city. International Journal of Chemical Sciences, 10(2), 635-642.

Paździor, K., Wrębiak, J., Klepacz-Smółka, A., Gmurek, M., Bilińska, L., Kos, L., ... \& Ledakowicz, S. (2017). Influence of ozonation and biodegradation on toxicity of industrial textile wastewater. Journal of environmental management, 195, 166-173. https://doi.org/10.1016/j.jenvman.2016.06.055

Pereira, J. A. R. (2002). Geração de resíduos industriais e controle ambiental. Centro Tecnológico da Universidade Federal do Pará. Pará.

Periyasamy, A. P., Rwahwire, S., \& Zhao, Y. (2017). Environmental Friendly Textile Processing. Handbook of $\quad$ Ecomaterials, https://doi.org/10.1007/978-3-319-68255-6_176

Phugare, S. S., Kalyani, D. C., Surwase, S. N., \& Jadhav, J. P. (2011). Ecofriendly degradation, decolorization and detoxification of textile effluent by a developed bacterial consortium. Ecotoxicology and environmental safety, 74(5), 1288-1296. https://doi.org/10.1016/j.ecoenv.2011.03.003 
Pierce, J. (1994). Colour in textile effluents-the origins of the problem. Journal of the Society of Dyers and Colourists, 110(4), 131-133. https://doi.org/10.1111/j.1478-4408.1994.tb01624.x

Powar, M. M., Kore, V. S., \& Kore, S. V. (2012). A case study on common effluent treatment plant at five star MIDC, Kagal. World J. Appl. Environ. Chem, 1(1), 1-6.

Prabha, S., Gogoi, A., Mazumder, P., Ramanathan, A. L., \& Kumar, M. (2017). Assessment of the impact of textile effluents on microbial diversity in Tirupur district, Tamil Nadu. Applied Water Science, 7(5), 2267-2277. https://doi.org/10.1007/s13201-016-0394-3

Prasad, A., \& Rao, K. V. B. (2011). Physicochemical analysis of textile effluent and decolorization of textile azo dye by Bacillus Endophyticus strain VITABR13. IIOAB J, 2(2), 55-62.

Premkumar, M. P., Thiruvengadaravi, K. V., Kumar, P. S., Nandagopal, J., \& Sivanesan, S. (2018). Eco-friendly treatment strategies for wastewater containing dyes and heavy metals. In Environmental Contaminants (pp. 317-360). Springer, Singapore. https://doi.org/10.1007/978-981-10-7332-8_14

Qadir, M., Schubert, S., Oster, J. D., Sposito, G., Minhas, P. S., Cheraghi, S. A., ... \& Saqib, M. (2018). High-magnesium waters and soils: Emerging environmental and food security constraints. Science of the Total Environment, 642, 1108-1117. https://doi.org/10.1016/j.scitotenv.2018.06.090

Radetski, C. M., Rosa, S. M. C., Rosa, E. V. C., De Souza Sierra, M. M., \& Simionatto, E. L. (2002). Ozonation of textile wastewater: physico-chemical and phytotoxic aspects. Environmental technology, 23(5), 537-545.

Rai, H. S., Bhattacharyya, M. S., Singh, J., Bansal, T. K., Vats, P., \& Banerjee, U. C. (2005). Removal of dyes from the effluent of textile and dyestuff manufacturing industry: a review of emerging techniques with reference to biological treatment. Critical reviews in environmental science and technology, 35(3), 219-238. https://doi.org/10.1080/10643380590917932

Raichurkar, P., \& Ramachandran, M. (2015). Recent trends and developments in textile industry in India. International Journal on Textile Engineering \& Processes, 1(4), 47-50.

Rajeshwari, K. V., Balakrishnan, M., Kansal, A., Lata, K., \& Kishore, V. V. N. (2000). State-of-the-art of anaerobic digestion technology for industrial wastewater treatment. Renewable and sustainable energy reviews, 4(2), 135-156. https://doi.org/10.1016/S1364-0321(99)00014-3

Ramesh, K., Balakrishnan, M., Vigneshkumar, B., Manju, A., Dhanakumar, S., Palanivel, M., \& Kalaiselvi, K. (2017). Removal of colour and chemical oxygen demand from textile effluent by Fenton oxidation method. Curr Sci, 113, 2112-2119.

Ramesh, S., \& Mekala, L. (2018). Treatment of textile waste water using Moring Oleifera and Tamarindus Indica. International Research Journal of Engineering and Technology, 5, 3891-3895. 
Rawlings, G. D., \& Samfield, M. (1979). Textile plant wastewater toxicity. Environmental Science \& Technology, 13(2), 160-164.

Rincón, G. J., \& La Motta, E. J. (2014). Simultaneous removal of oil and grease, and heavy metals from artificial bilge water using electro-coagulation/flotation. Journal of environmental management, 144, 42-50. https://doi.org/10.1016/j.jenvman.2014.05.004

Rodrigues, C. S., Madeira, L. M., \& Boaventura, R. A. (2013). Treatment of textile dye wastewaters using ferrous sulphate in a chemical coagulation/flocculation process. Environmental technology, 34(6), 719-729. https://doi.org/10.1080/09593330.2012.715679

Rompré, A., Servais, P., Baudart, J., De-Roubin, M. R., \& Laurent, P. (2002). Detection and enumeration of coliforms in drinking water: current methods and emerging approaches. Journal of microbiological methods, 49(1), 31-54. https://doi.org/10.1016/S0167-7012(01)00351-7

Roshini, P. S., Gandhimathi, R., Ramesh, S. T., \& Nidheesh, P. V. (2017). Combined electro-Fenton and biological processes for the treatment of industrial textile effluent: mineralization and toxicity analysis. Journal of Hazardous, Toxic, and Radioactive Waste, 21(4), 04017016.

Roy, C. K., Jahan, M. A. A., \& Rahman, S. S. (2018). Characterization and treatment of textile wastewater by aquatic plants (macrophytes) and algae. European Journal of Sustainable Development Research, 2(3), 29.

Saha, A. K., Sultana, N., Mohanta, M. K., Mandal, A., \& Haque, M. F. (2017). Identification and Characterization of Azo Dye Decolourizing Bacterial Strains, Alcaligenes faecalis E5. Cd and A. faecalis Fal. 3 Isolated from Textile Effluents. American Scientific Research Journal for Engineering, Technology, and Sciences (ASRJETS), 31(1), 163-175.

Salama, E. S., Saha, S., Kurade, M. B., Dev, S., Chang, S. W., \& Jeon, B. H. (2019). Recent trends in anaerobic co-digestion: Fat, oil, and grease (FOG) for enhanced biomethanation. Progress in Energy and Combustion Science, 70, 22-42. https://doi.org/10.1016/j.pecs.2018.08.002

Samudro, G., \& Mangkoedihardjo, S. (2010). Review on bod, cod and bod/cod ratio: a triangle zone for toxic, biodegradable and stable levels. International Journal of Academic Research, 2(4).

Sanchez, P. S., Sato, M. I., Paschoal, C. M., Alves, M. N., Furlan, E. V., \& Martins, M. T. (1988). Toxicity assessment of industrial effluents from S. Paulo state, Brazil, using short-term microbial assays. Toxicity assessment, 3(1), 55-80. https://doi.org/10.1002/tox.2540030107

Sánchez-Sánchez, A., Tejocote-Pérez, M., Fuentes-Rivas, R. M., Linares-Hernández, I., Martínez-Miranda, V., \& Fonseca-Montes de Oca, R. M. G. (2018). Treatment of a Textile Effluent by Electrochemical Oxidation and Coupled System Electooxidation-Salix babylonica. International Journal of Photoenergy (2018). 
https://doi.org/10.1155/2018/3147923

Sarayu, K., \& Sandhya, S. (2012). Current technologies for biological treatment of textile wastewater-a review. Applied biochemistry and biotechnology, 167(3), 645-661. https://doi.org/10.1007/s12010-012-9716-6

Sarma, S. J., \& Tay, J. H. (2018). Aerobic granulation for future wastewater treatment technology: challenges ahead. Environmental Science: Water Research \& Technology, 4(1), 9-15.

Sarvajith, M., Reddy, G. K. K., \& Nancharaiah, Y. V. (2018). Textile dye biodecolourization and ammonium removal over nitrite in aerobic granular sludge sequencing batch reactors. Journal of hazardous materials, 342, 536-543. https://doi.org/10.1039/C7EW00148G

Selcuk, H. (2005). Decolorization and detoxification of textile wastewater by ozonation and coagulation processes. Dyes and Pigments, 64(3), 217-222. https://doi.org/10.1016/j.dyepig.2004.03.020

Shenai, V. A. (2001). Non-ecofriendly textile chemicals and their probable substitutes-An overview.

Siddiqua, U. H., Ali, S., Iqbal, M., \& Hussain, T. (2017). Relationship between structure and dyeing properties of reactive dyes for cotton dyeing. Journal of Molecular Liquids, 241, 839-844. https://doi.org/10.1016/j.molliq.2017.04.057

Silva, L. G., Moreira, F. C., Souza, A. A., Souza, S. M., Boaventura, R. A., \& Vilar, V. J. (2018). Chemical and electrochemical advanced oxidation processes as a polishing step for textile wastewater treatment: A study regarding the discharge into the environment and the reuse in the textile industry. Journal of Cleaner Production, 198, 430-442. https://doi.org/10.1016/j.jclepro.2018.07.001

ŠImek, M., \& Cooper, J. E. (2002). The influence of soil pH on denitrification: progress towards the understanding of this interaction over the last 50 years. European Journal of Soil Science, 53(3), 345-354. https://doi.org/10.1046/j.1365-2389.2002.00461.x

Singare, P. U. (2019). Fluidized aerobic bio-reactor technology in treatment of textile effluent. $\begin{array}{llll}\text { Journal of Environmental Chemical Engineering, } & 7(1), \quad 102899 .\end{array}$ https://doi.org/10.1016/j.jece.2019.102899

Singare, P. U., \& Dhabarde, S. S. (2014). Pollution due to Textile Industries along Dombivali Industrial Belt of Mumbai, India. International Letters of Chemistry, Physics and Astronomy, 3, 24-31.

Singh, G., \& Iyer, G. V. (2004). Environmental impact studies of chrome rollers used by cotton roller ginning industries and design and development of pollution free chromeless RCF rollers. Environmental monitoring and assessment, 96(1-3), 163-181. https://doi.org/10.1023/B:EMAS.0000031725.88628.a3

Sivaram, N. M., Gopal, P. M., \& Barik, D. (2019). Toxic Waste From Textile Industries. In 
Energy from Toxic Organic Waste for Heat and Power Generation (pp. 43-54). Woodhead Publishing. https://doi.org/10.1016/B978-0-08-102528-4.00004-3

Smith, B. (1988). A workbook for pollution prevention by source reduction in textile wet processing. School of Textiles, North Carolina State University.

Souza, R. P., Ambrosio, E., Souza, M. T., Freitas, T. K., Ferrari-Lima, A. M., \& Garcia, J. C. (2017). Solar photocatalytic degradation of textile effluent with $\mathrm{TiO} 2$, ZnO, and $\mathrm{Nb} 2 \mathrm{O} 5$ catalysts: assessment of photocatalytic activity and mineralization. Environmental Science and Pollution Research, 24(14), 12691-12699. https://doi.org/10.1007/s11356-017-8408-8

Sponza, D. T. (2002). Necessity of toxicity assessment in Turkish industrial discharges (examples from metal and textile industry effluents). Environmental monitoring and assessment, 73(1), 41-66. https://doi.org/10.1023/A:1012663213153

Subrenat, A. S., \& Le Cloirec, P. A. (2006). Volatile organic compound (VOC) removal by adsorption onto activated carbon fiber cloth and electrothermal desorption: an industrial application. Chemical Engineering Communications, 193(4), 478-486. https://doi.org/10.1080/00986440500191768

Sudhanya, K. S., \& Chinnamma, M. A. (2018). Nano Scale Zero Valent Iron Particles for Dye Removal in Textile Industry and Treatment of Effluent. nanoscale, 2(5), 9-13.

Sultana, Z., Ali, M. E., Uddin, M. S., \& Haque, M. M. (2013). Study on implementation of effluent treatment plants for safe environment from textile waste. Journal of Research in environmental Science and Toxicology, 2(1), 9-16.

Tchamango, S. R., Kamdoum, O., Donfack, D., \& Babale, D. (2017). Comparison of electrocoagulation and chemical coagulation processes in the treatment of an effluent of a textile factory. Journal of Applied Sciences and Environmental Management, 21(7), 1317-1322. http://dx.doi.org/10.4314/jasem.v21i7.17

Tchounwou, P. B., Yedjou, C. G., Patlolla, A. K., \& Sutton, D. J. (2012). Heavy metal toxicity and the environment. In Molecular, clinical and environmental toxicology (pp. 133-164). Springer, Basel. https://doi.org/10.1007/978-3-7643-8340-4_6

Thompson, L. J. (2018). Sodium chloride (salt). In Veterinary Toxicology (pp. 479-482). Academic Press. https://doi.org/10.1016/B978-0-12-811410-0.00034-9

Tian, Y., He, W., Liang, D., Yang, W., Logan, B. E., \& Ren, N. (2018). Effective phosphate removal for advanced water treatment using low energy, migration electric-field assisted $\begin{array}{llll}\text { electrocoagulation. Water } \quad \text { research, } & 138, & 136 .\end{array}$ https://doi.org/10.1016/j.watres.2018.03.037

Tigini, V., Prigione, V., Giansanti, P., Mangiavillano, A., Pannocchia, A., \& Varese, G. C. (2010). Fungal biosorption, an innovative treatment for the decolourisation and detoxification of textile effluents. Water, 2(3), 550-565. https://doi.org/10.3390/w2030550

Todeschini, B. V., Cortimiglia, M. N., Callegaro-de-Menezes, D., \& Ghezzi, A. (2017). 
Innovative and sustainable business models in the fashion industry: Entrepreneurial drivers, $\begin{array}{llll}\text { opportunities, and challenges. Business Horizons, 60(6), } & \text { 759-770. }\end{array}$ https://doi.org/10.1016/j.bushor.2017.07.003

Tomei, M. C., Pascual, J. S., \& Angelucci, D. M. (2016). Analysing performance of real textile wastewater bio-decolourization under different reaction environments. Journal of cleaner production, 129, 468-477. https://doi.org/10.1016/j.jclepro.2016.04.028

Torres, L. G., Belloc, C., Vaca, M., Iturbe, R., \& Bandala, E. R. (2009). Coagulation-flocculation process applied to wastewaters generated in hydrocarbon-contaminated soil washing: Interactions among coagulant and flocculant concentrations and pH value. Journal of Environmental Science and Health, Part A, 44(13), 1449-1456. https://doi.org/10.1080/10934520903217716

Ulucan-Altuntas, K., \& Ilhan, F. (2018). Enhancing biodegradability of textile wastewater by ozonation processes: Optimization with response surface methodology. Ozone: Science \& Engineering, 40(6), 465-472. https://doi.org/10.1080/01919512.2018.1474339

Ummalyma, S. B., Pandey, A., Sukumaran, R. K., \& Sahoo, D. (2018). Bioremediation by microalgae: current and emerging trends for effluents treatments for value addition of waste streams. In Biosynthetic Technology and Environmental Challenges (pp. 355-375). Springer, Singapore. https://doi.org/10.1007/978-981-10-7434-9_19

United States Environmental Protection Agency - USEPA. (1993). Method 350.1: determination of ammonia nitrogen by semi-automated Colorimetry. Washington, DC.

United States Environmental Protection Agency - USEPA. (1993). Method 8260d: Volatile organic compounds by gas chromatography/mass spectrometry. Washington, DC.

United States Environmental Protection Agency - USEPA. (1994). Method 7062: antimony and arsenic (atomic absorption, borohydride reduction). Washington, DC.

United States Environmental Protection Agency - USEPA. (1997). Method 300.1: Determination of inorganic anions by ion chromatography. Washington, DC.

United States Environmental Protection Agency - USEPA. (2007). Method 6010c: Inductively coupled plasma-atomic emission spectrometry. Washington, DC.

Van Dam, R. A., Hogan, A. C., McCullough, C. D., Houston, M. A., Humphrey, C. L., \& Harford, A. J. (2010). Aquatic toxicity of magnesium sulfate, and the influence of calcium, in very low ionic concentration water. Environmental Toxicology and Chemistry, 29(2), 410-421.

Van der Bruggen, B., Canbolat, Ç. B., Lin, J., \& Luis, P. (2017). The potential of membrane technology for treatment of textile wastewater. In Sustainable Membrane Technology for Water and Wastewater Treatment (pp. 349-380). Springer, Singapore. https://doi.org/10.1007/978-981-10-5623-9_13

Verma, A. K., Dash, R. R., \& Bhunia, P. (2012). A review on chemical 
coagulation/flocculation technologies for removal of colour from textile wastewaters. Journal of environmental management, 93(1), 154-168. https://doi.org/10.1016/j.jenvman.2011.09.012

Verma, Y. (2008). Acute toxicity assessment of textile dyes and textile and dye industrial effluents using Daphnia magna bioassay. Toxicology and industrial health, 24(7), 491-500. https://doi.org/10.1177\%2F0748233708095769

Villegas-Navarro, A., González, M. R., Lopez, E. R., Aguilar, R. D., \& Marcal, W. S. (1999). Evaluation of Daphnia magna as an indicator of toxicity and treatment efficacy of textile wastewaters. Environment International, 619-624. https://doi.org/10.1016/S0160-4120(99)00034-3

Villegas-Navarro, A., Ramírez-M, Y., Salvador-SB, M. S., \& Gallardo, J. M. (2001). Determination of wastewater LC50 of the different process stages of the textile industry. Ecotoxicology and Environmental Safety, 48(1), 56-61. https://doi.org/10.1006/eesa.2000.1986

Wang, C., Yediler, A., Lienert, D., Wang, Z., \& Kettrup, A. (2002). Toxicity evaluation of reactive dyestuffs, auxiliaries and selected effluents in textile finishing industry to luminescent bacteria Vibrio fischeri. Chemosphere, 46(2), 339-344. https://doi.org/10.1016/S0045-6535(01)00086-8

Wang, W., \& Keturi, P. H. (1990). Comparative seed germination tests using ten plant species for toxicity assessment of a metal engraving effluent sample. Water, Air, and Soil Pollution, 52(3-4), 369-376. https://doi.org/10.1007/BF00229444

Weber-Scannell, P. K., \& Duffy, L. K. (2007). Effects of total dissolved solids on aquatic organism: a review of literature and recommendation for salmonid species. In American Journal of Environmental Sciences.

Wells, M. J. M., Rossano, A. J., \& Roberts, E. C. (1994). Textile wastewater effluent toxicity identification evaluation. Archives of Environmental Contamination and Toxicology, 27(4), 555-560. https://doi.org/10.1007/BF00214849

Wootton, J. T., Pfister, C. A., \& Forester, J. D. (2008). Dynamic patterns and ecological impacts of declining ocean $\mathrm{pH}$ in a high-resolution multi-year dataset. Proceedings of the National Academy of Sciences, 105(48), 18848-18853. https://doi.org/10.1073/pnas.0810079105

Wurts, W. A., \& Durborow, R. M. (1992). Interactions of pH, carbon dioxide, alkalinity and hardness in fish ponds.

Xu, H., Yang, B., Liu, Y., Li, F., Shen, C., Ma, C., ... \& Sand, W. (2018). Recent advances in anaerobic biological processes for textile printing and dyeing wastewater treatment: a mini-review. World Journal of Microbiology and Biotechnology, 34(11), 165. https://doi.org/10.1007/s11274-018-2548-y

Yan, T., Ye, Y., Ma, H., Zhang, Y., Guo, W., Du, B., ... \& Ngo, H. H. (2018). A critical review 


\section{Macrothink

on membrane hybrid system for nutrient recovery from wastewater. Chemical Engineering Journal. https://doi.org/10.1016/j.cej.2018.04.166

Yasar, A., Ahmad, N., Latif, H., \& Amanat Ali Khan, A. (2007). Pathogen re-growth in UASB effluent disinfected by UV, O3, H2O2, and advanced oxidation processes. Ozone: Science and Engineering, 29(6), 485-492. https://doi.org/10.1080/01919510701617710

Yusuff, R. O., \& Sonibare, J. A. (2004). Characterization of textile industries' effluents in Kaduna, Nigeria and pollution implications. Global Nest: the Int. J, 6(3), 212-221.

Zaharia, C., \& Suteu, D. (2013). Coal fly ash as adsorptive material for treatment of a real textile effluent: operating parameters and treatment efficiency. Environmental Science and Pollution Research, 20(4), 2226-2235. https://doi.org/10.1007/s11356-012-1065-z

Zhang, T., Ding, L., \& Ren, H. (2009). Pretreatment of ammonium removal from landfill leachate by chemical precipitation. Journal of Hazardous Materials, 166(2-3), 911-915. https://doi.org/10.1016/j.jhazmat.2008.11.101

Zhang, W., Liu, W., Zhang, J., Zhao, H., Zhang, Y., Quan, X., \& Jin, Y. (2012). Characterisation of acute toxicity, genotoxicity and oxidative stress posed by textile effluent on zebrafish. Journal of Environmental Sciences, 24(11) (2019)-2027. https://doi.org/10.1016/S1001-0742(11)61030-9

\section{Copyright}

Copyright for this article is retained by the author(s), with first publication rights granted to the journal.

This is an open-access article distributed under the terms and conditions of the Creative Commons Attribution license (http://creativecommons.org/licenses/by/4.0/). 